\title{
UNIVERSIDADE FEDERAL DE SANTA CATARINA PROGRAMA DE PÓS-GRADUAÇÃO EM LINGUÍSTICA
}

Ana Lúcia Pessotto dos Santos

\section{'PODE' E 'PODIA':}

UMA PROPOSTA SEMÂNTICO-PRAGMÁTICA

Dissertação de Mestrado apresentada ao Programa de Pós-graduação em Linguística da Universidade Federal de Santa Catarina como requisito à obtenção do título de Mestre em Linguística.

Orientação: Prof. Dra. Roberta Pires de Oliveira

Florianópolis 


\section{Catalogação na fonte pela Biblioteca Universitária da Universidade Federal de Santa Catarina}

P475p Pessotto, Ana Lúcia

Pode e podia [dissertação]: uma proposta semânticopragmática / Ana Lúcia Pessotto dos Santos ; orientadora, Roberta Pires de Oliveira. - Florianópolis, SC, 2011.

97 p.: il.

Dissertação (mestrado) - Universidade Federal de Santa Catarina, Centro de Comunicação e Expressão. Programa de Pós- Graduação em Linguística.

Inclui referências

1. Linguística. 2. Modalidade - (Linguística). 3. Possibilidade. 4. Imperfectividade. I. Oliveira, Roberta Pires de. II. Universidade Federal de Santa Catarina. Programa de Pós-Graduação em Linguística. III. Título. 


\title{
'PODE’ E 'PODIA': UMA PROPOSTA SEMÂNTICO- PRAGMÁTICA
}

Esta Dissertação foi julgada adequada para obtenção do Título de "Mestre", e aprovada em sua forma final pelo Programa de Pósgraduação em Linguística da Universidade Federal de Santa Catarina.

Florianópolis, 28 de fevereiro de 2011.

$$
\begin{gathered}
\text { Prof }^{\mathrm{a}} \text {., Dra }{ }^{\mathrm{a} . \text { Rosângela Hammes Rodrigues }} \\
\text { Coordenadora do programa }
\end{gathered}
$$

\section{Banca Examinadora:}

\author{
Prof. $^{\mathrm{a}}$, Dr. $^{\mathrm{a}}$ Roberta Pires de Oliveira \\ Orientadora \\ Universidade Federal de Santa Catarina (UFSC) \\ Prof., Dr. José Borges Neto, \\ Universidade Federal do Paraná (UFPR) \\ Prof., Dr. Cezar Augusto Mortari, \\ Universidade Federal de Santa Catarina (UFSC) \\ Prof. $^{\text {a }}$, Dr. ${ }^{\text {a }}$ Edair Maria Gorski, \\ Universidade Federal de Santa Catarina (UFSC) \\ Prof., Dr. Renato Miguel Basso, \\ Universidade Federal de Santa Catarina (UFSC)
}



Para Ignes e Bino, os melhores pais de todos os meus mundos possíveis.

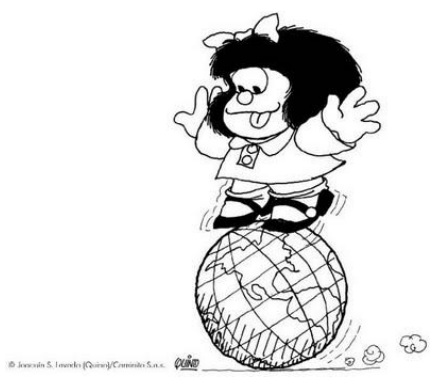





\section{AGRADECIMENTOS}

A Roberta, por confiar, acreditar, e me fazer acreditar também.

À Família de Sales (Valdir, Ediméya, Fê, Cris e Rô).

Aos amigos que contribuíram emprestando sua intuição e não me deixando esquecer que relaxar também faz parte do trabalho: colegas do mestrado, Cristina, Enrique, Família NUPILL, Gabriela, Guilherme, Ioana, Lara, Pessoal do NEG, Prisca, Rafaela, Sila, Talita, Thiago, Turma do Escritório, Veri e família, e a tantos outros, que a lista é enorme.

Ao Quino, por ter inventado a Mafalda.

Ao desconhecido da fila do café, que, numa conversa espontânea ouvida por mim por acaso, deu-me a epígrafe para este trabalho.

Ao Conselho Nacional de Desenvolvimento Científico e Tecnológico - CNPq e ao Programa de Pós-Graduação em Linguística $\mathrm{PPgL} / \mathrm{UFSC}$.

A todos os que, ao invés de pensar em termos de limitações, preferem pensar em termos de possibilidades. 

"Poder explicar isso eu não sei se eu posso... mas bem que eu podia..."

(Alguém, na fila do café.

UFSC, 2011) 



\section{RESUMO}

Este trabalho investiga a semântica de 'pode' e 'podia' no Português Brasileiro (PB) em contextos epistêmicos onde a possibilidade da proposição prejacente é orientada para o futuro (a partir do momento de fala). Com base na proposta de Kratzer (1981, 1991, 2008, 2010) sobre modalidade dependente do contexto, mostraremos que tanto 'pode' quanto 'podia' expressam possibilidade, e suas diferenças se devem à atuação do imperfeito, ausente em 'pode' e presente em 'podia'. Argumentamos que, quando não expressa passado, 'podia' veicula significados não proposicionais captados intuitivamente, como nãofactualidade e desejo. A proposta apresentada é que 'pode', onde morfema de imperfeito é ausente, restringe os mundos de avaliação (a base modal, segundo Kratzer) aos mundos mais próximos ao mundo real de acordo com um parâmetro de ordenação. Para usar 'pode' o falante precisa ter evidências que indiquem a factualidade do evento descrito pela prejacente, o que permite expressar uma possibilidade mais objetiva. Já para proferir 'podia' o falante não necessita de evidências que indiquem a factualidade do evento descrito pela prejacente, e então não promove restrição de mundos: o falante considera tanto mundos próximos quanto distantes do mundo real. Dessa falta de evidência, o falante veicula uma possibilidade mais subjetiva, mais característica de uma declaração de opinião do que de uma descrição de mundo. Da falta de evidência do falante ao expressar uma possibilidade, derivam outros significados, como o desejo do falante de que o evento descrito pela prejacente seja fato. Para fundamentar a análise desses significados não proposicionais, recorremos aos trabalhos de Iatridou (2000) sobre contrafactualidade e imperfectividade, Lyons (1977), sobre objetividade e subjetividade, e à proposta mista de Portner (2009), que mescla análise formal com uma visão discursiva inspirada em Stalnaker (1975).

Palavras-chave: modalidade, possibilidade, imperfectividade. 



\section{ABSTRACT}

This thesis investigates de semantic contribution of 'pode' (third person, present tense of the possibility verb 'poder') and 'podia' (third person, past imperfect tense of the same verb) in Brazilian Portuguese (BP), when both are used in epistemic future oriented contexts. Based on Kratzer's (1981, 1991, 2008, 2010) proposals about context dependent modality, I will show that both 'pode' and 'podia' express possibility. The differences between them are due to the imperfect contribution, which is the case in 'podia' but not in 'pode'. I argue that when the imperfect does not express past tense, it conveys intuitively captured non-propositional meanings, like non-factuality, desire, advice and politeness. The proposal presented here is that 'pode' restricts the worlds of evaluation (modal base) to those closer to the actual world according to a parameter of ordination (ordering source). To use a sentence with 'pode' the speaker must have evidences that support the factuality of the event described by the prejacent proposition, which allows her to express a possibility more objectively. On the other hand, to utter 'podia' the speaker does not need to have evidences to support the factuality of the prejacent, and so, does not restrict the modal base worlds. From this lack of evidence the speaker conveys a more subjective possibility, a declaration of opinion rather a description of the world. When the speaker expresses a possibility with lack of evidence to support it, other meanings can be derived, such as the speaker's desire that the event described by the prejacent sentence becomes true. To substantiate the analysis of the non-propositional meanings intuitively captured I turn to Iatridou's (2000) about imperfective and counterfactuality, Lyons's (1977) work about objectivity and subjectivity, and to the Portner (2009), who combines the formal analysis with a discoursive approach based on Stalnaker (1975).

Keywords: modality; possibility, imperfectivity. 



\section{LISTA DE FIGURAS}

Figura 1 - Estrutura do modal.......................................................41 



\section{SUMÁRIO}

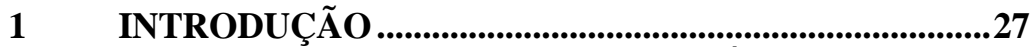

2 A TEORIA STANDARD SOBRE SEMÂNTICA

DE MODAIS..........................................................................37

2.1 DOIS TIPOS DE RACIOCÍNIO MODAL ……………………... 42

2.2 AS VÁRIAS INTERPRETAÇÕES DE 'PODE' E 'PODIA' ......... 47

$3 \quad$ PROPOSTAS MISTAS........................................................53

3.1 PORTNER (2009) E O COMMON PROPOSITIONAL SPACE 55

4 IMPERFECTIVIDADE.......................................................63

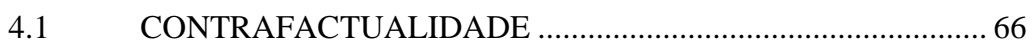

4.1.1 O fator de exclusão .....................................................................69

4.2 OS CONDICIONAIS IMPERFEITOS ………………………..... 71

5 ALÉM DA POSSIBILIDADE ...................................................77

5.1 (NÃO-) FACTUALIDADE …………………………………..... 77

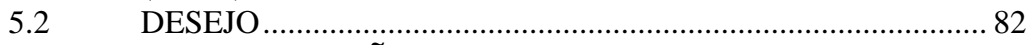

6 CONSIDERAÇÕES FINAIS....................................................8

REFERÊNCIAS BIBLIOGRÁFICAS ............................................93 



\section{INTRODUÇÃO}

A ideia que motivou o desenvolvimento deste trabalho foi preencher (ou pelo menos iniciar o preenchimento de) duas principais lacunas verificadas no quadro da pesquisa linguística sobre modalidade no Brasil. A primeira delas é a dificuldade em se encontrar, no Brasil, trabalhos sobre semântica da modalidade com base na perspectiva formal. Entendemos perspectiva formal como a visão baseada em teoria de mundos possíveis, para a qual a modalidade é estritamente a expressão da necessidade e da possibilidade, e os modais são quantificadores sobre mundos. Em geral, os estudos encontrados sobre semântica de modais no país até hoje são de perspectiva estruturalista como em Pontes (1973) e Lobato (1975) - ou funcionalista - como em Lyons (1977) e Moura Neves (1996) - em que a análise é direcionada pela sintaxe ou pelo posicionamento do falante. Com exceção do artigo de Pires de Oliveira e Scarduelli (2007), que trata da semântica de 'tem que' e 'deve', e da análise de Pires de Oliveira e Pessotto dos Santos (2009) em que buscam traçar as diferenças entre 'pode' e 'podia', não se encontra literatura nacional sobre semântica da modalidade baseada na perspectiva formal. A única referência em língua portuguesa sobre o assunto encontrada até então é a tese de doutorado de Maria de Fátima Oliveira, defendida em 1988 na Universidade do Porto, em que a autora analisa os modais 'dever' e 'poder' no português europeu (PE). Dessa leitura pode-se apreender que a análise feita para 'poder' no PE não corresponde totalmente ao que se verifica no português brasileiro (PB). Por exemplo, a autora não menciona que 'podia' expressa desejo do falante de forma generalizada, o que intuitivamente notamos que ocorre no PB. Essa é uma interpretação saliente atribuída à sentença:

\section{(1) Mafalda podia estar em casa agora.}

Em (1), além de expressar que Mafalda estar em casa é pouco plausível, o falante expressa seu desejo de que Mafalda esteja em casa ${ }^{1}$.

A segunda lacuna, que pode ser interpretada como decorrência da primeira, é a falta de pesquisa sobre a semântica da modalidade no PB

\footnotetext{
${ }^{1}$ Estamos cientes de que a entonação com o foco em 'podia' na sentença contribui para a interpretação de desejo, mas a investigação dos fenômenos prosódicos envolvidos, apesar de sua importância para esta pesquisa, está além do escopo deste trabalho.
} 
baseada na abordagem formal ${ }^{2}$. Também nesse caso, em que o PB é objeto de análise, os trabalhos encontrados são, em geral, de cunho estruturalista e funcionalista. Atualmente, dentro da abordagem formal, as pesquisas mais expressivas sobre semântica de verbos modais analisam o inglês e o alemão, e as características verificadas nessas línguas nem sempre condizem com o que se verifica no PB.

No inglês, algumas características dos verbos modais são apontadas Stowell (2004). Entre elas está a anomalia, já que algumas desses verbos, como must, ought, need, may e might, citados pelo autor, não apresentam alternância morfológica entre presente e passado. Em português, Ilari (1997) observa que o modal de necessidade 'dever' não assume todos os morfemas do indicativo, já que não pode ser usado como modal no pretérito perfeito e nem com leitura progressiva, como mostram a agramaticalidade das sentenças abaixo:

a.*Mafalda deveu sair.

b.* Mafalda está devendo sair.

Tais características, entretanto, não parecem, numa primeira análise, caracterizar o verbo 'poder', como mostra a aceitabilidade das sentenças abaixo:

a. Mafalda pôde sair.

b. Mafalda está podendo sair.

Apesar disso, o verbo 'poder' na forma 'podia' atende a outras características apontadas para os modais em inglês. Segundo Stowell (2004), os modais em inglês, como can e could, têm a interpretação presente/passado neutralizada em determinados contextos sintáticosemânticos. É o que acontece com 'pode' e 'podia' no PB, que em contextos orientados para o futuro perdem a distinção de tempo, já que 'podia', apesar de ter morfologia de pretérito imperfeito, não tem necessariamente interpretação de passado em todas as ocorrências. A sentença (4), por exemplo, é ambígua quanto ao tempo quando fora de contexto:

Mafalda podia viajar amanhã.

\footnotetext{
${ }^{2}$ Importante ressaltar que estamos observando a falta de trabalho sobre a semântica da modalidade no PB. Existem trabalhos dentro da abordagem formal sobre o PB em outras áreas, como sintaxe e aquisição de linguagem, os quais investigam auxiliaridade e modalidade. Entre esses trabalhos podemos citar Lunguinho (2005, 2010, entre outros).
} 
A sentença (4) pode expressar tanto (i) uma possibilidade passada de Mafalda viajar no dia seguinte ao momento de fala (MF), ou (ii) uma possibilidade presente, porém remota, de Mafalda viajar. Na leitura (i), a sentença expressa que em algum intervalo de tempo anterior ao momento de fala houve a possibilidade de Mafalda viajar no dia posterior ao MF. Condoravdi (2002) chama de "leitura metafísica", quando o modal é usado com uma perspectiva passada (sobre uma possibilidade passada). Na leitura metafísica o falante sabe sobre a factualidade do evento denotado pela proposição prejacente ${ }^{3}$, ou seja, ele sabe que Mafalda não foi viajar, o que gera uma leitura contrafactual.

A leitura (ii) da sentença veicula que no MF há a possibilidade presente de Mafalda viajar no dia seguinte. Nesse caso o modal é usado, segundo os termos de Condoravdi (2002), com uma perspectiva presente e com orientação futura, e o morfema de imperfeito '-ia' não expressa passado real. A autora denomina essa leitura de epistêmica, uma vez que a possibilidade está em aberto e é o conjunto de conhecimento do falante que o leva à conclusão de haver a possibilidade do evento descrito pela prejacente. Essa mesma interpretação, entretanto, é dada para uma sentença com 'pode'. A diferença entre (5.a) e (5.b), quando (5.b) recebe a segunda leitura, portanto, fica neutralizada no que diz respeito ao tempo, isto é, se elas diferem, essa diferença não é temporal:

a. Mafalda pode viajar amanhã.

b. Mafalda podia viajar amanhã.

Esta dissertação se concentra na leitura epistêmica conforme a classificação de Condoravdi (2002), na qual o modal é usado com a perspectiva presente e o evento denotado pela proposição prejacente tem orientação futura. O "podia' nessa leitura forma o "par mínimo"4 de análise com 'pode' e se diferencia de 'pode' por dois aspectos que serão analisados: (i) com 'podia' o falante expressa seu "distanciamento" em relação à factualidade da prejacente, que pode ser entendido como seu

\footnotetext{
${ }^{3} \mathrm{O}$ termo 'prejacente' foi usado primeiramente pelos estudiosos medievais para designar a proposição encaixada no modal, ou seja, a proposição sobre a qual o modal tem escopo (von Fintel e Iatridou, 2008). Utilizaremos esse termo para designar a proposição encaixada.

${ }^{4}$ Não é estranho que o imperfeito e o presente possam formar um "par mínimo" de análise, já que compartilham algumas características. Corôa (2005) aponta que tanto o presente quanto o imperfeito não colocam limites posteriores ao evento e ambos expressam habitualidade. Veja também Ferreira (2005).
} 
"descomprometimento" com a factualidade da prejacente e (ii) 'podia' veicula significados, que acreditamos ser não proposicionais, como polidez, sugestão/conselho e desejo do falante de que a prejacente $\mathrm{p}$ seja o caso. A leitura metafísica de 'podia', quando o morfema de imperfeito expressa passado, veicula contrafactualidade e não veicula desejo.

As interpretações de não-factualidade, polidez, conselho e desejo sobre a factualidade da prejacente, veiculadas por sentenças com 'podia' e não por sentenças com 'pode', nos levou à hipótese de que esses significados se devem à atuação do imperfeito, codificado pelo morfema '-ia'. Por essa razão, ao longo da pesquisa que originou este trabalho, verificou-se que compreender a diferença na contribuição semântica de 'pode' e 'podia' também passa pela compreensão da semântica da imperfectividade. Verificou-se que o que se observa em 'podia' está de acordo com o que a literatura sobre o imperfeito mostra para outras línguas, como o italiano (Ippolito, 2004), o francês (Hacquard, 2006) e o grego (Iatridou, 2000), em que o imperfeito é responsável por veicular não-factualidade. A análise do imperfeito neste trabalho será baseada em estudos sobre os condicionais, realizados por Iatridou (2000), Ippolito (2004) e Stalnaker (1975). Uma vez que autores como Kratzer (1981) tratam condicionais como modais, e uma vez que identificamos muitas das características do imperfeito no PB nas análises encontradas, como, por exemplo, a veiculação de contrafactualidade por sentenças com imperfeito, esperamos que esses estudos sejam adequados para a explicação da atuação do imperfeito em 'podia'.

Apesar de na tradição gramatical o "passado inconcluso" ser apontado como o principal significado veiculado pela morfologia de imperfeito (Ilari, 1997; Corôa, 2005), há na língua outras leituras veiculadas por essa morfologia. Nesse caso, o imperfeito expressa progressão. A sentença:

(6) Mafalda dormia quando Susanita chegou.

expressa que o momento da chegada de Susanita está incluído no momento em que Mafalda dormia, ou seja, o evento de Mafalda dormir estava em andamento quando ocorreu o evento da chegada de Sofia. Em outras palavras, o momento do evento está incluído no momento de referência (imperfectividade) e ambos são anteriores ao momento de 
fala (passado) ${ }^{5,6}$. Mas a morfologia de imperfeito também veicula hábito, como em (7):

$$
\text { Mafalda tomava café todos os dias. }
$$

A sentença (7) expressa que Mafalda costumava, ou tinha o hábito de tomar café todos os dias.

Além disso, o morfema de imperfeito veicula implicaturas. Em (7), por exemplo, o imperfeito 'tomava' implica que Mafalda não toma mais café. Entretanto esse significado pode ser cancelado, como mostra o exemplo:

$$
\text { Mafalda tomava café todos os dias e ainda toma. }
$$

Caso a interpretação de que Mafalda não toma mais café fosse semântica, a sentença soaria contraditória. Dado que a leitura de que Mafalda não toma mais café pode ser cancelada, ela é uma implicatura conversacional disparada pelo imperfeito. Nesses moldes, a nãofactualidade do evento descrito pela prejacente veiculada por 'podia' também pode ser considerada uma implicatura. Imagine que Mafalda está esperando o telefonema de seu médico para saber o resultado de um exame. Mafalda profere:

Meu médico podia me ligar amanhã.

A sentença (9) veicula (i) que Mafalda acha pouco possível que o médico vá ligar amanhã e (ii) que Mafalda deseja que ele ligue amanhã. A leitura (i) não convém ser considerada como acarretamento, já que 'o médico ligar' está orientada para o futuro, e o futuro está sempre em aberto: ele tanto pode ligar quanto não ligar. A questão que emerge é por que Mafalda falaria sobre uma possibilidade que ela não acredita que se torne real? A hipótese é que essa seja outra implicatura disparada por construções modais imperfectivas. Se o falante fala de uma possibilidade para a qual ele não tem nenhuma evidência, é porque ele tem a intenção de veicular outra coisa. A não-factualidade veiculada pelo morfema de imperfeito pode explicar, por exemplo, como a

\footnotetext{
${ }^{5}$ No PB usa-se na língua oral a perífrase auxiliar-IMP + gerúndio para a expressão do progressivo, como em (i):

(i) Mafalda estava dormindo quando Susanita chegou.

${ }^{6}$ Os usos habitual e progressivo são explorados em Ferreira (2005), que trata o imperfeito como um operador que pluraliza eventos.
} 
sentença (5.b) acima pode expressar o desejo do falante de que Mafalda viaje amanhã: o falante fala de uma possibilidade na qual não acredita porque quer expressar seu desejo de que ela seja o caso.

Intuitivamente a não-factualidade é uma característica dos modais, pois, para expressarmos a possibilidade de alguma coisa acontecer, é necessário que essa coisa ainda não seja fato, ou que, no mínimo, não saibamos nada sobre sua factualidade. Não proferimos as sentenças abaixo se sabemos que está chovendo, a menos que queiramos ser irônicos ${ }^{7}$ :

a. Pode chover.

b. Podia chover.

Nesse sentido, tanto 'pode' quanto 'podia', como expressam possibilidade, implicam a não-factualidade da sentença prejacente. Em outras palavras, supõe-se, por implicatura, que no fundo conversacional (contexto) em que o falante se baseia para proferir as sentenças acima, devem estar disponíveis tanto mundos em que chove (pelo menos um) quanto mundos em que não chove. A semântica da possibilidade apenas nos assegura semanticamente que há pelo menos um mundo em que chove, ou seja, que 'não estar chovendo' não é uma necessidade.

Em um segundo sentido há a não-factualidade que se refere à interpretação de que o falante veicula que não tem evidências de que a prejacente será fato. Por exemplo, em:

$$
\text { Mafalda podia viajar (amanhã). }
$$

a interpretação de que Mafalda não vai viajar é não-factual no sentido de que, apesar de haver a possibilidade, o falante veicula que Mafalda viajar não se tornará fato. É a esse segundo sentido a que nos referiremos quando usarmos os termos 'não-factualidade' e 'nãofactual', uma vez que estamos analisando casos orientados para o futuro, em que o falante não tem conhecimento sobre a factualidade da prejacente. Devemos a ideia de não-factualidade à leitura do trabalho de Oliveira (1988), que trata dos modais 'dever' e 'poder' no PE. De forma distinta, a contrafactualidade, conforme Iatridou (2000), refere-se àquilo

\footnotetext{
${ }^{7}$ A ironia é uma operação pragmática. Pela visão da lógica não há nada de errado em dizer 'Pode chover' se sabemos que está chovendo, já que p acarreta a possibilidade de $\mathrm{p}$ (se algo ocorre, então é porque é possível). Em língua natural não dizemos pode-p quando sabemos que p é o caso porque assim estaríamos quebrando a máxima griceana da quantidade: um falante cooperativo dá o máximo de informação que tem.
} 
que é contrário aos fatos, portanto algo só pode ser contrafactual ao presente ou ao passado, nunca ao futuro já que o futuro (ainda) não é fato.

Dado esse quadro geral, este trabalho defende que a expressão de "distanciamento" do falante sobre a factualidade da proposição prejacente veiculada pelo imperfeito constitui a principal diferença entre 'pode' e 'podia', apesar de ambos expressarem possibilidade. Segundo Ippolito (2004) e Iatridou (2000), que analisam, respectivamente, o italiano e o grego - os quais, como o PB, codificam no morfema de imperfeito tanto tempo (pretérito) como aspecto (imperfeito) -, mostram que o imperfeito pode expressar dois significados: o temporal e o modal. Quando o significado é temporal, o morfema expressa passado real, deslocando o evento descrito pelo verbo para o passado, para um momento anterior ao momento de fala. Já quando o significado expresso pelo imperfeito é modal, o morfema de imperfeito expressa passado "falso", ou seja, não causa deslocamento no tempo, mas desloca o falante da sua situação (mundo) real. Enquanto Ippolito (2004) foca sua análise na contribuição do passado, essa dissertação se volta para a investigação do significado modal do imperfeito.

Como já adiantamos, a modalidade será considerada aqui com base na perspectiva formal, e a análise será conforme a teoria standard ${ }^{8}$ sobre semântica de modais, proposta por Angelika Kratzer (1981, 1991, 2008 , 2010). Sua proposta introduziu duas ideias principais no estudo da modalidade (Portner, 2009): a modalidade relativa, em que a interpretação dos modais é contextualmente dependente; e a semântica de ordenação, que capta a noção de gradualidade em sentenças modais, ou seja, explica como podemos interpretar algo como mais ou menos possível. O tipo de semântica usada por Kratzer é a semântica de vizinhança, a qual usa a noção de mundos possíveis, mas é mais geral do que a semântica de mundos possíveis clássica, ou relacional. $\mathrm{Na}$ semântica relacional um modelo é definido por uma tripla ordenada $<\mathrm{W}$, $\mathrm{R}, \mathrm{V}>$, onde $\mathrm{W}$ é um conjunto de mundos possíveis, $\mathrm{R}$ é uma relação binária de acessibilidade entre mundos e $\mathrm{V}$ uma valoração. A semântica de vizinhança, por sua vez, substitui a relação entre mundos por uma função de mundo para conjuntos de mundos. A definição do modelo mantém $\mathrm{W}$ e $\mathrm{V}$, mas substitui $\mathrm{R}$ por $f$, formando a tripla $\langle\mathrm{W}, f, \mathrm{~V}\rangle$, em

\footnotetext{
${ }^{8}$ Standard é o termo usado por Portner (2009) para se referir à teoria de Kratzer sobre modais. O termo 'canon' (cânone, ou teoria canônica) é usado por von Fintel (2007, entre outros). Neste trabalho preferimos o termo de Portner (2009).
} 
que $f$ é uma função de mapeamento entre um mundo possível e um conjunto de mundos possíveis.

$\mathrm{Na}$ perspectiva formal, expressões modais são operadores sobre proposições: eles operam sobre uma proposição e geram outra proposição. A proposição, por sua vez, denota o conjunto de mundos. Modais de possibilidade correspondem à quantificação existencial sobre mundos (há pelo menos um mundo no universo de mundos possíveis em que a sentença é verdadeira) e modais de necessidade correspondem à quantificação universal sobre mundos (em todos os mundos do universo de mundos possíveis a sentença é verdadeira). Sendo assim, modais são operadores sobre (conjuntos de) mundos possíveis.

De forma esquemática, temos em (12.b) e (12.c) a representação de (12.a):

(12) a. Mafalda pode tomar o trem.

b. Mafalda pode tomar o trem.
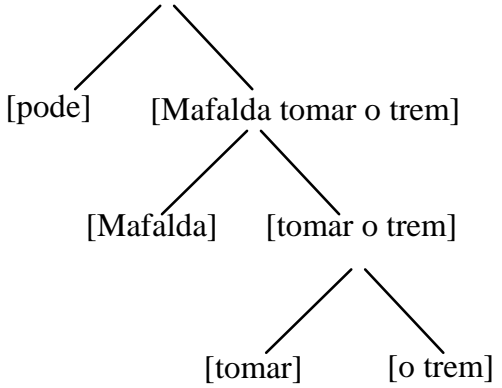

c. [Pode [Mafalda tomar o trem]]

Abstraindo as operações de flexão, o exemplo mostra o operador de possibilidade 'pode' tomando a proposição infinitiva (aqui chamada de prejacente) 'Mafalda tomar o trem' como escopo e formando uma nova proposição, a modalizada 'Mafalda pode tomar o trem'.

Não vamos nos ater à investigação da leitura deôntica, pois o foco dessa dissertação é a leitura epistêmica. Entretanto é importante citar o trabalho de Hacquard (2006), onde a autora mostra como a diferença entre modais epistêmicos e modais de raiz (onde se incluem os deônticos) pode ser derivada de seu ambiente sintático. Em outras palavras, modais apresentam diferentes bases modais porque eles projetam sua base modal, constituída por diferentes tipos de evento ou 
situação, em estágios diferentes da composição semântica. Segundo essa análise, modais epistêmicos têm esse significado por se localizarem acima do tempo (tense), uma posição sintática que dá acesso à situação de fala e, por isso, ao falante e ao seu conhecimento. Nas regiões mais baixas das projeções verbais, argumentos de eventos ou situações dão acesso aos participantes e ao ambiente espaço-temporal dos eventos descritos. A discussão sobre a modalidade relativa e o conceito de base modal será realizada no capítulo 2, em que será apresentada a proposta standard de Kratzer $(1981,1991,2008,2010)$ para a semântica de modais.

Considerando que uma análise mais completa da semântica de 'pode' e 'podia' passa pela compreensão dos significados nãoproposicionais veiculados pelo segundo e não pelo primeiro, o capítulo 3 será dedicado a apresentar propostas que combinam análise semântica com análise pragmática para explicar o significado dos modais. Entre essas propostas vamos discutir especialmente a de Portner (2009), que mescla a semântica dinâmica com a noção de fundo conversacional compartilhado (common ground) de Stalnaker para propor o common propositional space (espaço proposicional comum, ou CPS). O CPS é um superconjunto do fundo conversacional que contém proposições candidatas a serem incluídas no fundo conversacional pelos participantes da conversa. Veremos como essa proposta pode ajudar a explicar a veiculação dos significados não-proposicionais de 'podia'.

As questões de tempo e aspecto que envolvem a semântica de 'pode' e 'podia', em especial a imperfectividade, serão discutidas no capítulo 4. O capítulo inicia com a apresentação das intuições de Corôa (2005) e Ilari (1997) sobre o tempo em PB. Nas subseções seguintes vamos apresentar a proposta do fator de exclusão de Iatridou (2000) para tratar dos contrafactuais, e veremos que sua intuição, apesar de correta, não é suficiente para explicar como podemos expressar nãofactualidade quando o falante é ignorante sobre a factualidade da prejacente.

No capítulo 5 e 6 usaremos o arcabouço teórico apresentado e as análises construídas ao longo dos capítulos anteriores, acrescentando a análise griceana (Grice, 1975) sobre implicaturas conversacionais para tratar dos significados canceláveis veiculados por 'pode' e 'podia', como não-factualidade, desejo, sugestão e polidez. A hipótese defendida é que esses significados canceláveis podem ser derivados de operações formais, em especial da restrição de mundos realizada por 'pode' e não por 'podia', proposta que iremos apresentar nesse quarto capítulo. $\mathrm{O}$ 
capítulo 6 será dedicado às considerações finais e a apontar o trabalho que ainda precisa ser desenvolvido.

Espera-se que o estudo apresentado nesta dissertação contribua para a compreensão da modalidade e do imperfeito no PB, e que essa contribuição possa ser estendida para outras línguas, além de incentivar as pesquisas sobre modais em PB dentro da perspectiva formal. 


\section{A TEORIA STANDARD SOBRE SEMÂNTICA DE MODAIS}

Neste capítulo será apresentada a teoria standard sobre semântica de modais dentro da abordagem formal, a qual foi desenvolvida por Angelika Kratzer em uma série de artigos publicados de 1977 a 1991, dos quais a partir de 2008 novas versões passaram a ser disponibilizadas para serem reeditadas pela Oxford University Press ${ }^{9}$. Como já dissemos há duas grandes contribuições da autora. Uma contribuição foi formalizar a intuição de que, apesar da variedade de significados expressos por um modal (conhecimento, obrigatoriedade, permissão, entre outros), todos esses tipos de modalidade têm um significado comum, e as várias interpretações são determinadas pelo contexto. Não se trata, portanto, de uma ambiguidade dos modais, mas de indeterminação semântica. Além disso, o trabalho da autora contribuiu, não só para a Linguística, mas inclusive para a Filosofia, com a proposta da fonte de ordenação, que tornou possível explicar a noção de gradualidade - o que nos permite falar que algo é mais, ou menos, possível. Essa abordagem deu origem à chamada semântica de ordenação. Nesta primeira parte, vamos apresentar as linhas gerais da proposta de Kratzer, introduzindo conceitos básicos. Especial atenção será dada nas subseções seguintes aos conceitos de base modal e fonte de ordenação, analisando se a combinação de 'pode' e 'podia' com as diferentes bases e fontes é suficiente para explicar as diferenças entre eles. Finalmente serão apresentados os conceitos de necessidade e possibilidade construídos a partir da definição de base modal e fonte de ordenação dentro da proposta da autora.

Como dissemos, trabalho de Kratzer trouxe importante contribuição teórica também para a Filosofia, especialmente no campo da Lógica, de onde vem o instrumental para a análise formal da semântica de língua natural. A linguagem lógica modal usa um operador para cada tipo de modalidade, cada um com sua semântica, pois parte da idéia de que cada tipo de modalidade estabelece um tipo de relação entre mundos. Por exemplo, há um operador para representar permissão ('é permitido que...)', outro para modalidade epistêmica ('é possível, dado o que se sabe...'), e assim por diante. A abordagem da lógica modal é problemática se o objetivo for descrever as línguas naturais, especialmente por causa das questões de aquisição de linguagem: seria complicado explicar como uma criança adquiriria todos os significados

\footnotetext{
${ }^{9}$ As novas versões dos textos de Kratzer estão disponíveis em <http://semanticsarchive.net/cgibin/browse.pl?search=angelika $>$.
} 
representados por cada operador diferente. Além disso, a lógica modal não capta o significado comum a todas as expressões que expressam possibilidade (ou necessidade). Finalmente, a lógica modal analisa possibilidade e necessidade em termos de compatibilidade e consequência lógicas:

Compatibilidade lógica: uma proposição $p$ é compatível com um conjunto de proposições $A$ se, e somente se, $A \cup\{p\}$ é consistente.

Consistência: um conjunto de proposições $A$ é consistente se, e somente se, há um mundo em $W$ em que todas as proposições de $A$ são verdadeiras.

Consequência lógica: Uma proposição $p$ se segue de um conjunto de proposições $A$ se, e somente se, $p$ é verdadeira em todos os mundos em que todas as proposições de $A$ são verdadeiras.

Nessa análise, uma proposição é possível se for compatível com dado conjunto de proposições, e necessária se for consequência lógica desse conjunto. Ou seja, não há como analisar uma proposição como mais, ou menos, possível. Entretanto faz parte da nossa capacidade semântica expressar e interpretar um "significado comum" e também falarmos sobre diferentes graus de possibilidade. Esse é um fato empiricamente observado, dada a ocorrência de sentenças como:
a. Mafalda pode sair.
b. É mais provável que Mafalda saia do que fique em casa.

A sentença (13.a) pode expressar ou permissão, ou capacidade, ou o conhecimento do falante sobre Mafalda sair. Entretanto o significado de possibilidade se mantém, dadas as paráfrases como: "Ela pode sair porque o pai dela permite"; "Ela pode sair porque é fisicamente capaz"; "Ela pode sair porque, dado o que eu sei, eu infiro que não é necessário que ela fique em casa.”. Na sentença (13.b), o falante compara possibilidades, expressando que Mafalda sair é uma possibilidade melhor do que Mafalda ficar em casa.

Para dar conta dessas limitações da análise lógica na descrição das línguas naturais, Kratzer $(1991,2008)$ defende que as expressões 
modais têm um significado central (common core), o qual conecta todas as ocorrências do modal e permanece invariável, independente do contexto. Segundo a autora, esse significado central deve ser captado pela análise semântica (Kratzer, 2008, p.7), mas também as suas diferentes interpretações devem ser mimetizadas por um modelo semântico. Esses aspectos, que caracterizam uma sentença modal, são descritos como os três ingredientes do modal: a força modal, a base modal e a fonte de ordenação. A força modal é o único desses ingredientes que é dado pelo item lexical. Ela determina se o modal tem força de necessidade ou de possibilidade (por exemplo 'poder' e 'é possível que' entre outros expressam possibilidade; 'ter que' e 'necessariamente' expressam necessidade, etc.). Os vários significados desempenhados pelos modais, ou seja, as várias interpretações que a eles podem ser dadas (epistêmica, deôntica, teleológica, etc.) são determinadas relativamente ao fundo conversacional, composto por dois tipos de informação contextual: a base modal e a fonte de ordenação.

Com base no modelo da semântica de vizinhança, e dado que proposições denotam conjuntos de mundos possíveis, Kratzer (1991, p. $641 ; 2010$, p. 11) define fundo conversacional como uma função de contexto que atribui a cada mundo de $\mathrm{W}$ um conjunto de proposições relevantes naquele contexto. Dado que proposições são conjuntos de mundo, a função de contexto atribui a cada mundo de $\mathrm{W}$ um conjunto de conjuntos de mundos, em outras palavras, um subconjunto do conjunto potência de W. Por exemplo, o significado de 'dado o que eu sei sobre...' mapeia um mundo possível w a um conjunto de proposições A (conjunto de conjuntos de mundos) que caracteriza o que se sabe naquele mundo w. $\mathrm{O}$ resultado da aplicação dessa função será a base modal, ou seja, o conjunto de mundos que compartilham fatos relevantes para avaliarmos uma proposição modal no mundo tomado como mundo de avaliação (na maioria das vezes, o mundo real do falante, o nosso mundo).

O segundo elemento do fundo conversacional é a fonte de ordenação, o qual Kratzer introduz para dar conta da noção de gradualidade. Como já mencionamos, nas línguas naturais há expressões como 'é pouco possível que' ou 'é mais provável que' ou 'p é tão possível quanto q', as quais expressam gradualidade além do estritamente possível e do necessário. A fonte de ordenação organiza os mundos da base modal de modo que alguns mundos fiquem mais distantes e outros mais próximos de mundos considerados ideais, dado um parâmetro contextual. Quanto mais próximo dos mundos ideais a fonte de ordenação coloca o mundo, mais possível ele é. Kratzer (1991) 
define a fonte de ordenação com base em Lewis (1981), como um conjunto de proposições A que induz uma ordenação $\leq_{\mathrm{A}}$ em W (conjunto de mundos) da seguinte maneira:

para todo w,w' que pertencem a $\mathrm{W}$, para qualquer $\mathrm{A} \subseteq \mathrm{B}(\mathrm{W}): \mathrm{w} \leq_{\mathrm{A}} \mathrm{w}^{\prime}$ sse $\left\{\mathrm{p}: \mathrm{p} \in \mathrm{A}\right.$ e $\left.\mathrm{w}^{\prime} \in \mathrm{p}\right\} \subseteq\{\mathrm{p}:$ $\mathrm{p} \in \mathrm{A}$ e $\mathrm{w} \in \mathrm{p}\}$

Em outras palavras, um mundo w está tão próximo dos ideais representados por A quanto w' se todas as proposições de A que são verdadeiras em w' são também verdadeiras em w.

Por relacionarem o contexto com uma sentença, os modais são, para Kartzer (2008), predicados de dois lugares cujos argumentos são uma restrição modal e um escopo modal. A restrição modal é dada pelo contexto e pode ser linguisticamente expressa por frases "restritivas" como "O que se sabe", ou "o que a lei prediz". Essa restrição corresponde à base modal. $\mathrm{O}$ segundo argumento, o escopo modal, corresponde à proposição prejacente. Portanto a interpretação da sentença modalizada é sempre relativa, como mostram as sentenças:

a. O Brasil pode se tornar uma grande potência.

b. Tendo em vista o que se sabe, o Brasil pode se tornar uma grande potência.

Quando a restrição modal é dada explicitamente por sentenças como 'tendo em vista o que se sabe', como em (14.b), caracteriza-se, segundo Kratzer (1991), um modal neutro. Já quando a restrição é implicitamente dada pelo contexto, caracteriza-se um modal não-neutro. Quando a restrição modal não está explícita, como em (14.a), o significado do modal não-neutro é preenchido por informações contextuais. Conforme a autora coloca:

...the only difference between neutral and nonneutral modals, then, is that the kind of modality is linguistically specified in the former, but provided by the non-linguistic context in the latter. Modality is always relative modality. (Kratzer, 1991, p. 640, grifo nosso) $^{10}$

\footnotetext{
${ }^{10}$ A única diferença entre modais neutros e não-neutros, então, é que o tipo de modalidade vem linguisticamente especificado no primeiro, mas fornecido pelo contexto não linguístico no segundo. Modalidade é sempre modalidade relativa. (tradução nossa).
} 
A figura a seguir representa um esquema das partes que compõem o significado de (14.b):

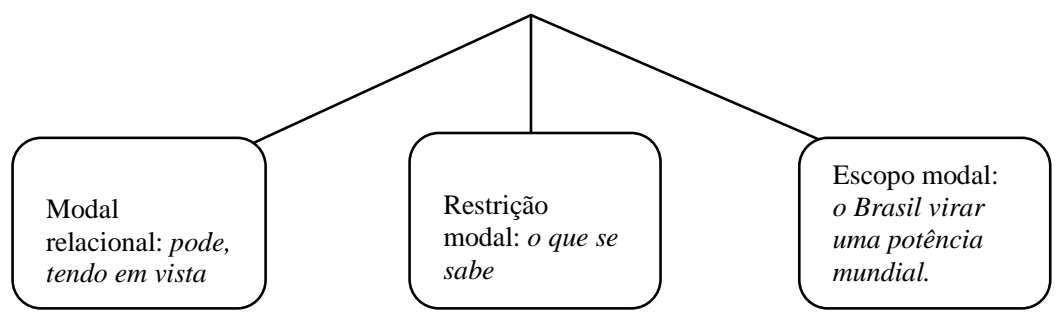

Figura 1 - Estrutura do modal.

Fonte: Kratzer (2008, p.7)

Se o modal neutro em (14.b) requer esses dois argumentos, o significado semântico central de todas as ocorrências de 'pode' deve requerer esses argumentos também. Assim, a diferença entre (14.a) e (14.b), é que enquanto a segunda traz explícitos os dois argumentos, a primeira explicita somente o escopo modal. A combinação da restrição modal com o significado central do modal é o que dá a variedade de interpretações (Kratzer, 2008).

A partir dos conceitos de base modal e fonte de ordenação Kratzer constrói as definições graduais de necessidade e possibilidade, sendo elas: necessidade, boa possibilidade, possibilidade, possibilidade tão boa quanto, melhor possibilidade, necessidade fraca e possibilidade pequena $^{11}$. Em especial, para este trabalho, nos interessa os conceitos de necessidade e possibilidade, que são apresentados a seguir. Segundo Kratzer (1991: 644):

Uma proposição p é uma necessidade em um mundo w com respeito a uma base modal $f$ e uma fonte de ordenação g se, e somente se, a seguinte condição for satisfeita: para todo $\mathrm{u} \epsilon \cap \mathrm{f}(\mathrm{w})$ há um mundo $\mathrm{v} \in \cap \mathrm{f}(\mathrm{w})$ tal que $\mathrm{v} \leq_{\mathrm{g}(\mathrm{w})} \mathrm{u}$ e para todo $\mathrm{z} \epsilon$ $\cap f(w):$ se $z \leq_{g(w)} v$, então $z \in p$.

11 O termo "pequena" foi usado aqui como tentativa de traduzir o termo "slight" usado pela autora (slight possibility). Preferiu-se não usar o termo "fraca" neste caso, pois "fraca" traduz "weak" de "weak necessity (possibilidade fraca). 
Uma proposição $\mathrm{p}$ é uma possibilidade em um mundo w com respeito a uma base modal $f$ e uma fonte de ordenação g se, e somente se, $\neg$ p não é uma necessidade em $\mathrm{w}$ com respeito a $\mathrm{f}$ e $\mathrm{g}$.

A definição de necessidade nos diz que uma proposição p é uma necessidade se, para cada mundo u pertencente à base modal: se há um mundo v, também pertencente à base modal, tal que $\mathrm{v}$ é melhor ordenado que $\mathrm{u}, \mathrm{e}$ (ii) para todo o mundo $\mathrm{z}$ que também pertença à base modal, se $\mathrm{z}$ for melhor ordenado que $\mathrm{v}, \mathrm{z}$ pertence a $\mathrm{p}$ ( $\mathrm{p}$ é verdadeira em z).

Por sua vez, a definição de possibilidade nos diz que uma proposição $\mathrm{p}$ é possível em um mundo $\mathrm{w}$ somente se a negação $\neg$ p não for uma necessidade em w. Em outras palavras, há pelo menos um mundo entre os mundos próximos aos ideais definidos pela fonte de ordenação em que p é verdadeira. Nesta dissertação, assumimos que tanto 'pode' quanto 'podia' semanticamente expressam possibilidade nesses termos.

\subsection{DOIS TIPOS DE RACIOCÍNIO MODAL}

As bases modais representam formas modais de raciocinar, e Kratzer $(1981,1991)$ identifica duas: a epistêmica e a circunstancial. Ambas são bases realistas, atribuem a cada mundo possível o conjunto de proposições verdadeiras naquele mundo. A diferença entre essas bases foi um problema levantado por Kratzer (1981, 1991), mas deixado em aberto. Naquele momento, a autora considerou a existência de dois tipos de modais lexicalmente distintos, os quais difeririam entre si por selecionar dois tipos de bases modais semanticamente distintas: modais de raiz (não-epistêmicos) selecionariam semanticamente a base circunstancial, e modais epistêmicos selecionariam base epistêmica (Kratzer, 2010, p. 3).

No entanto, essa diferença mostrou-se difícil de captar, e mesmo os textos da autora não dão uma distinção clara. Algumas características sobre essa distinção, entretanto, foram apontadas por Kratzer $(1981,1991)$. Segundo ela, uma leitura puramente circunstancial é caracterizada por uma base modal circunstancial e uma fonte de ordenação vazia ou não. O conjunto de informação relevante nesse caso é formado por observações pontuais e locais. Já uma leitura epistêmica é dada por uma base modal epistêmica, com uma fonte de ordenação (vazia ou não) e o que conta é o conjunto completo de evidências 
disponíveis. A leitura circunstancial é o resultado do raciocínio de arquitetos ou engenheiros sobre o que pode ser feito dado certos fatos relevantes. Já a leitura epistêmica é a leitura do historiador e do investigador, que questionam o que pode ter sido o caso dados todos os fatos relevantes.

Conforme essa análise de Kratzer (1991), analisamos sentenças com 'pode' e 'podia' e duas questões principais se colocam. Primeiro, como diferenciar se uma sentença com 'pode' ou 'podia' tem base epistêmica ou circunstancial? E segundo, será que a diferenciação semântica entre bases modais é capaz de diferenciar 'pode' e 'podia'? Ou será que eles se combinam com as duas bases indiscriminadamente?

Usando o exemplo adaptado de Kratzer (1991) imagine que você chegue a um lugar pela primeira vez e, verificando evidências locais como condições do solo, umidade, temperatura e luminosidade, conclui que são condições ideais para plantar hortênsias, pois as condições observadas são muito semelhantes às de lugares do mundo onde há hortênsias por toda parte. Essa seria a descrição da base circunstancial. Você então profere:

a. Pode crescer hortênsias nessa região.

b. Podia crescer hortênsias nessa região ${ }^{12}$.

Ambas as sentenças acima parecem adequadas na situação descrita. Ou seja, tanto 'pode' quanto 'podia' aceitam uma leitura circunstancial, conforme os moldes de Kratzer (1991).

Em outra situação, você chega a um lugar pela primeira vez e sabe que esse lugar nunca teve contato com lugares onde crescem hortênsias, e que a vegetação desse lugar é muito diferente da vegetação de lugares onde crescem hortênsias. Nessa situação, que caracteriza a base epistêmica, as sentenças acima seriam falsas. Segundo Kratzer, nesse caso é a evidência completa disponível que conta para o raciocínio modal. Mas a autora não deixa claro qual a natureza dessa evidência.

Eis outro exemplo de base epistêmica: houve um assassinato, mas não sabemos quem foi o assassino. Sabemos como foi o crime, a arma usada, a hora aproximada. Suponha que estamos conjecturando sobre quem foi o assassino. Levamos em conta as pessoas que normalmente tinham contato com a vítima e sabemos, entre outras

\footnotetext{
${ }^{12}$ Como observaremos mais adiante, há trabalhos em sociolinguística que atestam que o imperfeito e o futuro do pretérito estão em variação no PB. Entretanto é intuitivo que 'podia' (imperfeito) e 'poderia' (futuro do pretérito) não dão a mesma contribuição semântica. Não vamos investigar essa diferença aqui.
} 
pessoas, que Mafalda é a governanta da casa. Nessa situação podemos dizer: 'O assassino pode ser a Mafalda' e também 'O assassino podia ser a Mafalda', embora proferir a segunda sentença dispare implicaturas. Aparentemente, 'pode' e 'podia' são efetivamente substituíveis na base circunstancial. A dificuldade na distinção das bases modais parece ter sido esclarecida com o trabalho de Hacquard (2006). Hacquard (2006) argumenta que a distinção entre modais epistêmicos e de raiz, antes os chamados circunstanciais, não é semântica, como proposto por Kratzer, mas sim derivada do seu ambiente sintático. Na recente reedição de Notional Category of Modality, Kratzer (2010) cita o trabalho de Hacquard (2006) e admite:

Through Hacquard's work I have since learned why it was so difficult (if not impossible) to characterize that difference semantically. The modal bases for root and epistemic modals depend on particular types of facts, and I took that to mean that there are two types of lexically distinguished modals that differ in selecting two types of semantically distinguished modal bases: circumstantial modal bases for root modals and epistemic modal bases for epistemic modals. That was all wrong. (Kratzer, 2010, p.3)

Para Kratzer (2010), o trabalho de Hacquard (2006) apresenta um grande avanço na teoria da modalidade nas línguas naturais:

Her proposal does not only explain why there is a pervasive split between root and epistemic modals in the languages of the world. It also tells us how modal base dependencies can be syntactically represented in natural languages: via event or situation arguments from which possibilities can be projected in predictable ways. No separate

\footnotetext{
${ }^{13}$ Por meio do trabalho de Hacquard eu entendi porquê era tão difícil (se não impossível) caracterizar aquela diferença semanticamente. As bases modais para modais de raiz e modais epistêmicos dependem de tipos de fatos em particular, e eu entendi isso como se existissem dois tipos de modais lexicalmente distintos que diferem por selecionarem dois tipos de bases modais semanticamente diferentes: bases modais circunstanciais para modais de raiz e bases modais epistêmicas para modais epistêmicos. Aquilo estava tudo errado. (Kratzer, 2010, p.3) (Tradução nossa).
} 
representation for modal bases is needed. $(\text { Kratzer, 2010, p. } 4)^{14}$

Com base em Haqcuard (2006), Kratzer (2010) reformula sua ideia de base modal assumindo que a base epistêmica avalia o conhecimento sobre o presente e o passado. Já a base circunstancial (ou de raiz) baseia-se em inferências sobre o que é possível de acontecer no futuro.

Sobre essa nova proposta de base modal, damos o seguinte exemplo. Imagine que, nas eleições de 2010, você conheceu os candidatos e estava informado sobre qual era o dia da votação. No dia da eleição, entretanto, você teve que viajar para algum lugar ermo do planeta e não pôde acompanhar a apuração. Você não teve como saber quem ganhou a eleição. Nessa situação, daquele lugar ermo onde você está no dia da eleição, você pode proferir:

a. A Dilma pode ter sido eleita.

b. \# A Dilma podia ter sido eleita.

Dado que Dilma era uma das candidatas e dado que você eventualmente tenha visto pesquisas que apontavam a vitória de Dilma, com base nesse conhecimento você expressa a possibilidade de Dilma ter sido eleita. Esse exemplo caracteriza, portanto, uma base modal epistêmica. Em (16.a) você usa o seu conhecimento sobre circunstâncias presentes e passadas (não-futuras) para inferir a possibilidade de Dilma ter sido eleita. Já a sentença (16.b) não parece adequada nesse contexto. A sentença (16.b) é adequada em contextos, conforme a classificação de Condoravdi (2002), de modalidade metafísica, em que o falante sabe sobre a factualidade da situação descrita pela prejacente. Nesse caso, a sentença (16.b) seria adequada se o falante sabe que Dilma não foi eleita e veicula que houve um momento no passado em que a situação de vitória de Dilma foi possível, mas ela não ocorreu. Essa é a leitura contrafactual.

Dado esse exemplo, pode parecer que 'podia' não é compatível com uma base epistêmica em que o falante não conhece os fatos e

\footnotetext{
${ }^{14}$ Sua proposta não somente explica porquê há uma grande diferença entre modais epistêmicos e de raiz nas línguas do mundo. Ela também nos diz como a dependência das bases modais podem ser representada sintaticamente nas línguas naturais. Via argumentos de evento ou situação de onde as possibilidades podem ser projetadas de maneira previsível. Nenhuma outra representação para as bases modais se faz necessária. (Kratzer, 2010, p. 4) (Tradução nossa).
} 
raciocina sobre a possibilidade deles. Para mostrar que 'podia' pode ser epistêmico nesse sentido, vamos usar o exemplo do assassinato. Imagine que houve um assassinato e não se sabe quem foi o assassino. A polícia está investigando e, conforme as informações que reúne, o inspetor de polícia profere (17.a) ou (17.b):

a. O mordomo pode ser o assassino.

b. O mordomo podia ser o assassino.

Ambas expressam a possibilidade de o mordomo ser o assassino. A diferença entre elas é que em (17.a) o inspetor veicula mais certeza sobre a possibilidade do mordomo ser o assassino, ao passo que com (17.b) veicula menos certeza. A sentença (17.b) seria adequada para ser falada pelo inspetor, por exemplo, no início da investigação, quando se tem menos informação sobre o caso e as possibilidades são mais amplas. À medida que as investigações se desenvolvem e mais informações são reunidas, o inspetor pode mudar sua fala e proferir (17.a). Essa questão de 'podia' expressar uma possibilidade mais "fraca" será melhor discutida nos capítulos seguintes. Por enquanto é suficiente mostrar que 'podia', assim como 'pode', pode ser usado em contextos epistêmicos.

Para explicar a base circunstancial, considere agora um contexto anterior ao dia das eleições. Você está acompanhando as candidaturas, as campanhas e as pesquisas. Sabendo que a Dilma é candidata (que por si garante a possibilidade de ela ser eleita) você profere:

a. Dilma pode ser eleita.

b. Dilma podia ser eleita.

Com as sentenças acima o falante expressa a possibilidade de Dilma ser eleita nas eleições que estão por vir, ou seja, ele avalia as evidências disponíveis para ele no presente e conjectura sobre a possibilidade de ela ser eleita no futuro. A diferença entre (18.a) e (18.b) portanto não está no tipo de base modal, pois, como podemos ver, ambas se combinam com base circunstancial. A diferença está em que, para proferir (18.a) o falante precisa de mais conhecimento sobre a situação, uma informação a mais que transmita a ele mais certeza sobre a possibilidade da situação descrita pela prejacente se tornar fato. Por exemplo, além de saber que Dilma é candidata, você viu as pesquisas apontarem sua vitória. Já com a sentença (18.b) o falante, além de expressar possibilidade, veicula que a possibilidade de Dilma ser eleita é menor em comparação com a 
sentença (18.a), porque as evidências que o falante tem sobre essa possibilidade não são suficientes para ele expressar uma possibilidade mais restrita, ou objetiva.

A análise desse exemplo introduz uma das ideias propostas nesta dissertação, a de que, para proferir uma sentença com 'pode', o falante deve ter evidência sobre a situação descrita pela sentença. Essa ideia será melhor explorada ao longo desta dissertação.

\subsection{FONTES DE ORDENAÇÃO E AS VÁRIAS INTERPRETAÇÕES DE 'PODE' E 'PODIA'}

Nessa seção vamos mostrar os diferentes significados veiculados por 'pode' e 'podia' com base na proposta de fonte de ordenação de Kratzer (1991). Como vimos anteriormente, a base modal atribui a cada mundo w um conjunto de mundos possíveis compatíveis com w. Conforme Kratzer (1991), esses mundos podem estar mais próximos ou mais distantes dos mundos ideais, determinados por um parâmetro contextual, a fonte de ordenação. Não há uma lista definida de quantas e quais são as fontes de ordenação, mas entre as mais comuns, que são apontadas por Kratzer (1991) e às quais nos atemos aqui, estão: a fonte deôntica, cujo parâmetro é o que a lei prediz; a fonte teleológica, cujo parâmetro é um objetivo a ser alcançado; a fonte estereotípica, cujo parâmetro é o curso normal dos eventos; e a bulética, cujo parâmetro é aquilo que se deseja. Dentro desse quadro, analisamos como essas diferentes interpretações são provocadas conforme a combinação de 'pode' e 'podia' com as fontes de ordenação.

Um dos sentidos em que o verbo 'poder' é usado, e, por conseguinte, suas formas como 'pode' e 'podia', é no sentido de conceder uma permissão. A essa leitura chamamos de leitura deôntica. Sendo o parâmetro da fonte deôntica um conjunto de leis e regras, imagine a seguinte situação. Para que Mafalda possa sair à noite, ela precisa da autorização do pai dela. O conjunto de regras nesse caso é o conjunto das regras impostas pelo pai de Mafalda. O pai de Mafalda então profere:

(19) Mafalda pode sair à noite.

A sentença expressa que, conforme as regras determinadas pelo pai, é permitido que Mafalda saia à noite. Os mundos ideais representados pelo parâmetro deôntico são aqueles em que as regras do pai são obedecidas. Uma possibilidade, nesse contexto, significa que dentre os 
mundos próximos aos ideais, há pelo menos um em que Mafalda sai à noite. Em outros termos, os mundos próximos aos ideais não podem ser todos mundos em que Mafalda não sai à noite. Por outro lado, a sentença:

(20) Mafalda podia sair à noite.

só se combina adequadamente com a fonte deôntica quando não é orientada para o futuro, ou seja, quando o morfema de imperfeito está realmente se referindo ao passado. A sentença (20) expressa que, conforme as regras do pai, havia a permissão, no passado, de Mafalda sair à noite. Enquanto ao proferir a sentença (19) o pai pode estar realizando um ato de fala performativo, ou seja, ele concede a permissão ao proferir a sentença, em (20) a sentença não é um ato de fala performativo, mas somente um relato de uma permissão concedida no passado. Portanto, no que concerne à fonte de ordenação, tanto 'pode' quanto 'podia' têm leitura deôntica, apenas quando 'podia' expressa passado. A diferença está na expressão de tempo e na realização de ato de fala. Nesta dissertação, não iremos desenvolver a modalidade deôntica, porque nessa modalidade o morfema de imperfeito expressa tempo, e estamos preocupados em explorar o significado modal do imperfeito.

Outra leitura veiculada por 'pode' e 'podia' é o telelógico, ou seja, leva em conta o que pode ser feito para um objetivo ser alcançado. Imagine que Mafalda brigou com o namorado e está se sentindo mal por isso. Sua mãe, vendo o sofrimento da filha, conversa com o pai de Mafalda sobre o que fazer para diminuir seu mal-estar. Nesse caso, o pai de Mafalda profere ou (21.a) ou (21.b):

a. A Mafalda pode pedir desculpas pra ele.

b. A Mafalda podia pedir desculpas pra ele.

As sentenças expressam que pedir desculpas ao namorado é uma maneira de Mafalda alcançar o objetivo de diminuir seu mal-estar. Os mundos ideais são aqueles em que é diminuído o mal-estar de Mafalda e os mundos são ordenados de modo que próximo aos ideais há pelo menos um em que ela pede desculpas. Nesse caso, verifica-se que tanto 'pode' quanto 'podia' se combinam com a fonte teleológica. A diferença entre (21.a) e (21.b) portanto não está na fonte de ordenação, nem no tempo da possibilidade (na perspectiva), nem no tempo de 
orientação, mas possivelmente em fatores de ordem pragmática desencadeados por 'podia', como implicatura de conselho ou polidez.

A expressão de polidez não será explorada nesse trabalho, mas merece ser mencionada já que é recorrente em sentenças com imperfeito. Por exemplo, Mafalda vai à padaria e, ao se dirigir ao atendente, pode proferir a ou b:
a. Eu quero 4 pães.
b. Eu queria 4 pães.

Apesar da morfologia de (22.b), tanto com (22.a) quanto com (22.b) Mafalda expressa que quer 4 pães no momento em que profere a sentença. Nesse contexto, não faz sentido Mafalda dizer (22.b) querendo expressar que no passado ela queria pães. A diferença entre (22.a) e (22.b) está sim na atuação do imperfeito, mas não no tempo. Com ele, Mafalda parece se "distanciar" do mundo real, ou seja, expressa um descomprometimento com a verdade da proposição prejacente. Assim, ela diminui sua força em persuadir o interlocutor a concordar com ela, no mínimo dando a ele espaço para que ele decida se vai lhe dar os pães. Esse pode ser uma caminho a ser explorado para explicar a veiculação de polidez, o que retomaremos nas considerações finais.

A fonte estereotípica é aquela determinada pelo que o falante sabe sobre o curso normal dos eventos. Ao proferir uma sentença modal com base epistêmica e fonte estereotípica, o falante realiza uma inferência do tipo 'Dado o que eu sei sobre como é o curso normal dos acontecimentos, concluo que é possível que p'. A situação-exemplo agora é uma situação metereológica. Faz muito tempo que não chove, o tempo está abafado e há muitas nuvens escuras no céu. Esse cenário indica que é possível que chova, caso os acontecimentos se desenvolvam normalmente. Sabendo disso o falante profere (23.a) ou (23.b):
(23)
a. Pode chover.
b. Podia chover.

Tanto (23.a) como (23.b) são adequadas para serem proferidas em um contexto estereotípico: dado que o tempo está abafado e há muitas nuvens no céu, pode/podia chover. Os mundos ideais são aqueles em que os acontecimentos seguem seu curso normal (não há nenhum acidente metereológico, por exemplo) e a fonte estereotípica ordena os 
mundos de modo que, próximo aos ideais, há pelo menos um mundo em que chove.

Entretanto, considerar que tanto 'pode' quanto 'podia', quando orientados para o futuro, se combinam com a fonte estereotípica vai contra a proposta esboçada nesse trabalho. Propomos, como será detalhado nos capítulos adiante, que uma sentença com 'pode' restringe os mundos da base modal àqueles mais próximos ao real, dado um parâmetro de ordenação. Esse parâmetro é estabelecido porque há evidências sobre o curso normal dos eventos. Quando não existem evidências suficientes sobre o curso dos acontecimentos não há ordenação, ou seja, a fonte de ordenação é vazia e o falante opta por usar 'podia', que não restringe os mundos: apenas veicula que dentre a totalidade de mundos de avaliação há um em que a prejacente é o caso, e pode ou não ser próximo ao mundo real, veiculando uma possibilidade mais ampla. Dada essa análise, seria correto afirmar que uma diferença entre 'pode' e 'podia' é que o primeiro promove ordenação estereotípica e o segundo não.

De qualquer forma, podemos dizer que a combinação de 'pode' e 'podia' com a fonte estereotípica funciona como a combinação com a fonte deôntica: tanto 'pode' quanto 'podia' se combinam com a fonte estereotípica quando 'podia' expressa tempo, pois a proposta da restrição de mundos, a princípio, não impede que o falante possa basearse no curso normal de acontecimentos passados para expressar uma possibilidade passada. Até o momento não temos uma explicação mais clara para essa situação.

Seja como for, é forte a relação entre as evidências disponíveis ao falante e a escolha entre 'pode' e 'podia'. O fator que diferencia (23.a) e (23.b), é um traço não-factual presente em 'podia' e não em 'pode'. Com (23.b) o falante veicula, além da possibilidade de que, conforme o andamento normal dos eventos, chova, que a possibilidade de chuva é pouca. Já em (23.a) o falante não coloca esse posicionamento, apenas expressa a possibilidade de forma neutra. A diferença aqui está relacionada com a discussão introduzida na seção anterior sobre o conhecimento que o falante tem sobre a situação. Nesta dissertação propõe-se que para proferir a sentença (23.a) o falante precisa de uma informação que garanta mais certeza quanto à possibilidade de chuva. Ambas as sentenças são adequadas para expressarem a possibilidade de chuva, afinal a possibilidade de chover é trivial: chover, até onde sabemos, é sempre uma possibilidade (pelo menos em mundos compatíveis com o nosso, em que a natureza se comporta como a nossa). Entretanto a sentença (23.a) não é adequada 
para um contexto em que o falante não tem nenhuma evidência de chuva, enquanto (23.b) o é. E se chover é uma possibilidade trivial no sentido que descrevemos acima, porque proferir (23.a) ou (23.b)? Porque o falante que expressa tais sentenças não só expressam possibilidade como também implicam sua "aposta" de que a prejacente será fato com (23.a) e implica que a prejacente tende a não denotar um fato com (23.b). Os capítulos finais serão dedicados à apresentação dessa análise.

A última fonte de ordenação que será discutida aqui é a fonte bulética, a qual organiza os mundos da base modal de acordo com o que é desejado. A literatura (Kratzer, 1991, 2008; Portner, 2009) não deixa claro de quem é esse desejo, se é do falante ou do sujeito da sentença. Mas dado que, empiricamente, a interpretação veiculada por sentenças com 'podia' é de que elas expressam o desejo do falante de que a sentença prejacente seja um fato, assume-se aqui que o desejo é o do falante. Considerando o mesmo cenário metereológico descrito anteriormente, o falante está sofrendo com o clima abafado e deseja muito que o tempo refresque. Nessa situação ele profere (24.b), mas não pode proferir (24.a) com felicidade:
a. \# Pode chover ${ }^{15}$.
b. Podia chover.

A sentença (24.b) expressa o desejo do falante de que chova. Já (24.a) não veicula interpretação de desejo. Portanto, 'podia' pode selecionar fonte bulética, mas 'pode' parece não poder. Os mundos ideais são aqueles em que se realizam os desejos do falante. Como veremos no capítulo 5 sobre implicaturas, essa análise gera um problema para a interpretação de 'podia' como expressão de possibilidade.

Vamos argumentar que uma explicação melhor para a interpretação de desejo suscitada apenas por 'podia' é considerar esses significados como implicaturas conversacionais generalizadas no PB. O argumento para essa proposta é que 'podia' sempre expressa possibilidade, mas em alguns contextos pode também expressar esses outros significados, intimamente relacionados com a subjetividade, ou posicionamento do falante, o que será tema da seção seguinte.

Neste capítulo, analisamos 'pode' e 'podia' com base na proposta de Kratzer (1981, 1991, 2008, 2010) sobre semântica de modais. Mostramos que a combinação de 'pode' e 'podia' com as bases

\footnotetext{
${ }^{15}$ Usamos o símbolo \# para indicar incompatibilidade de 'pode' com a fonte bulética.
} 
modais não é suficiente para diferenciá-los, já que tanto sentenças com 'pode' quanto sentenças com 'podia' são adequadamente proferidas tanto na base epistêmica quanto na base de raiz. Também analisamos a compatibilidade de 'pode' e 'podia' com as fontes de ordenação mais conhecidas: a estereotípica, a deôntica, a teleológica e a bulética. Dessa análise, concluímos que a fonte teleológica (cujo parâmetro são os objeticvos alcançados) não diferencia 'pode' e 'podia', dado que ambos se combinam adequadamente com elas, e as diferenças que aparecem entre eles são de caráter pragmático. Observamos também que, no que concerne à fonte de ordenação, tanto 'pode' quanto 'podia' têm leitura deôntica e estereotípica, mas eles não formam um par mínimo. 'Podia' só tem leitura deôntica quando o morfema de imperfeito expressa passado real (ver exemplos (19) e (20)) e, ao contrário de 'pode', não expressa um ato de fala performativo, apenas um relato de permissão. A combinação com a fonte estereotípica (cujo parâmetro é a ordem normal dos acontecimentos) pode diferenciar 'pode' de 'podia' nas mesmas condições da fonte deôntica. Finalmente, mostramos que 'pode' não veicula desejo do falante ao contrário de 'podia', o que nos indica que 'podia' é compatível com a fonte de ordenação bulética enquanto 'pode' não é. Mas como veremos no capítulo 4, a explicação do desejo via fonte de ordenação nos traz problemas, dado que a expressão do desejo é cancelável e, portanto, não pode ser resultado de operações formais.

Nesta seção mostramos alguns dos significados mais comumente captados em sentenças com 'pode' e 'podia'. Diferente de uma descrição puramente intuitiva, procuramos mostrar esses significados com base na proposta de Kratzer (1981, 1991, 2008), em que os diferentes significados dos modais dependem de parâmetros contextuais, as chamadas fontes de ordenação, além da base modal.

A seguir apresentaremos propostas que mesclam a abordagem formal com uma visão discursiva (dinâmica) da semântica. 


\section{PROPOSTAS MISTAS}

Neste capítulo serão apresentadas algumas propostas importantes que tratam da subjetividade veiculada pelos modais, tema cuja principal referência para este trabalho é Lyons (1977). O trabalho desse autor influenciou propostas recentes que mesclam semântica e pragmática com o intuito de fornecerem uma análise mais completa do significado das expressões modais. Nossa intenção é mostrar como essas propostas mistas vêm ganhando espaço nos últimos anos e considerá-las para a explicação dos significados não proposicionais veiculados por 'pode' e 'podia', em especial a partir da leitura de Portner (2009).

Algumas propostas formais recentes (Ninan, 2005; von Fintel e Gillies, 2007; Portner, 2009) sugerem que uma descrição completa dos modais vai além da análise vericondicional, isto é, das condições de verdade da sentença. Os modais não só contribuem para as condições de verdade por meio de quantificação sobre mundos, mas também disparam ato(s) de fala relacionado(s) à sentença prejacente, os quais expressam o posicionamento, a avaliação do falante. A ideia dos modais como veiculadores de atos de fala remete ao trabalho de Lyons (1977), cuja intuição sobre a subjetividade dos modais merece destaque, uma vez que serve de respaldo para as propostas mistas formais mais recentes consideradas nesta dissertação. Segundo Lyons (1977), algumas expressões modais epistêmicas são usadas para expressar a avaliação subjetiva do falante sobre uma proposição, enquanto outras expressam a probabilidade efetiva de a proposição ser verdadeira.

Para Lyons (1977), a interpretação de uma proposição modalizada muda conforme o tipo de conhecimento e o nível de comprometimento que o falante tem com a verdade ou factualidade da sentença prejacente. Em sentenças objetivamente modalizadas o falante está comprometido com a factualidade da informação veiculada, ou seja, ele está realizando um ato de descrição de mundo baseado em evidências que o levam a inferir a existência de uma possibilidade "real", por assim dizer. A sentença objetivamente modalizada pode ser aceita, questionada, concordada, etc., pelo interlocutor, uma vez que as evidências que a ancoram podem ser checadas.

Já em sentenças subjetivamente modalizadas o falante não afirma que há a possibilidade real da prejacente ser verdadeira, mas sim expressa uma avaliação sobre a factualidade da situação: sua pouca confiança que a situação expressa pela prejacente será verdade, por exemplo. São mais declarações de opinião, do que propriamente descrições de possibilidades reais. Segundo Lyons (1977), assertar uma 
sentença declarativa é em si um ato de fala, mas modais epistêmicos subjetivos modificam esse ato de fala de tal forma que a sentença que contém esse modal realiza um ato de fala mais fraco que a asserção. Assim, a sentença (25.a) é mais "forte" que a sentença (25.b):
a. Mafalda está em casa.
b. Mafalda pode estar em casa.

Entretanto Lyons (1977) não deixa claro qual a natureza desse ato de fala "mais fraco". Uma sugestão sobre a natureza desse ato de fala é dada por Kratzer (1981). Analisando o alemão, para a autora uma interpretação subjetiva aparece naquela língua quando a fonte de ordenação contém "superstições" ou outras assunções "não objetivas". A autora não oferece uma análise profunda, mas vale citá-la para mostrar que a relação entre subjetividade e crença parece intuitiva entre alguns autores. Para Tancredi (apud Portner, 2009), por exemplo, a modalidade epistêmica subjetiva é, na verdade, doxástica, ou seja, baseada nas crenças do falante e não no seu conhecimento.

Por exemplo, imagine o contexto da festa de aniversário de Susanita para a qual Mafalda foi convidada. Só que Mafalda está viajando, e Susanita não espera, ou crê, que ela compareça, pois não tem evid6encioa pra isso. Alguém bate à porta e Susanita profere:
a. \# Pode ser a Mafalda.
b. Podia ser a Mafalda.

A sentença (26.a) é inapropriada para a situação porque, apesar de ser compatível com o conhecimento de Susanita (Mafalda foi convidada), não é compatível com sua crença sobre o comparecimento de Mafalda. Logo, por tudo o que Susanita sabe, não há a possibilidade real de ser Mafalda. Já (26.b) é possível porque parece expressar a subjetividade do falante, seu desejo de que seja Mafalda. Tancredi (2007) argumenta que a semântica da sentença não é dada apenas pelo que o falante sabe, mas também pelo que ele acredita ser verdade. Ou seja, a sentença pode ser verdadeira de acordo com o conhecimento de Lara, mas é inapropriada pragmaticamente, dado que fere a máxima griceana da qualidade: não dizer o que se acredita ser falso.

As implicaturas são assunto do capítulo 5, mas cabe aqui introduzir mais uma diferença entre 'pode' e 'podia'. Como representado em (26), a sentença modalizada com 'podia' é adequada na situação da festa descrita acima. Apesar de ser um exemplo 
contrafactual (Lara sabe que não pode ser Mafalda), esse fato está relacionado com o traço de não-factualidade expresso por 'podia' com o que, apesar de expressar possibilidade, o falante expressa também sua falta de evidência de que a prejacente denote uma verdade. $\mathrm{O}$ mesmo ocorre em contextos não-factuais, em que o falante, ao invés de ter uma evidência contra a factualidade da prejacente como em (26), simplesmente não tem evidência nenhuma, e mesmo assim profere uma sentença com 'podia'. Voltaremos a esse assunto.

A subjetividade também é pensada por Nuyts (2001), para quem ela tem a ver com a natureza da evidência que ancora uma declaração epistêmica. Dois pontos devem ser levados em conta, segundo o autor: (i) a qualidade da evidência e (ii) se a evidência é compartilhada entre o falante e outros membros da conversa ou se a evidência é disponível apenas para o falante. Por esse viés, portanto, a subjetividade deve ser pensada como um componente evidencial, pois pode expressar se o falante profere a sentença modalizada com base em evidência direta, inferência ou por ouvir dizer.

$\mathrm{Na}$ tentativa de complementar a análise formal com ideias da semântica discursiva, von Fintel e Gillies (2007) propõem que ao proferir uma sentença modal o falante tanto asserta uma proposição modal quanto "profere (com uma explícita falta de convicção)"16, ou "alerta para não descartar a possibilidade" de que o fato descrito pela prejacente é o caso. Portner (2009) critica e acrescenta ideias a essa proposta. Primeiro, porque os autores não deixam claro o que é proferir ou dar um alerta, ou aviso. Segundo porque, para Portner (2009), além de assertar o falante que usa uma sentença com modal epistêmico também compartilha a prejacente (não-modal) como possibilidade.

\subsection{PORTNER (2009) E O COMMON PROPOSITIONAL SPACE}

A análise de Kratzer é um tipo de análise chamada de estática, pois não considera os efeitos que as sentenças podem causar no contexto. Para dar conta desses efeitos existe a proposta dinâmica, que considera a proposição pelo seu potencial de mudança de contexto

\footnotetext{
${ }^{16}$ No original, os autores analisam a sentença: '(19) There might have been a mistake' e sugerem: "Our suggestion is that a sentence like (19) is used to make two speech acts: an assertion that is compatible with the evidence that there has been a mistake, and proffering (with an explicit lack of conviction) that there has been a mistake or giving advice not to overlook the possibility. That there has been a mistake." (von Fintel e Gillies, 2007, p.44). Em nota, os próprios autores alertam para o fato de que o conceito de asserção como ato de fala deve ser repensado e que o segundo ato de fala precisa ser melhor caracterizado.
} 
(context change potential), ou CCP. Segundo essa propriedade, cada proposição assertada (ou seja, aceita como relevante no contexto) atualiza um estado de informação (EI) inicial i adicionando informação a ele e gerando um estado de informação i'. Na analogia com a linguagem de programação, proposições são como programas que, dados como input num sistema, geram um output atualizado.

Por exemplo, o EI inicial de uma pessoa que está dentro de uma casa fechada é de total ignorância sobre o fato de estar ou não chovendo lá fora. Sendo p a representação da sentença 'Está chovendo', o EI inicial da pessoa em estado de ignorância contém p e $\neg$ p. Essa ideia lembra a noção de não-factualidade apresentada na introdução: para alguma coisa ser possível (semântica e pragmaticamente) é preciso que tanto a sentença quanto sua negação estejam disponíveis para denotarem um fato. No momento em que alguém entra na casa e profere $p$, a sentença vai atualizar o EI da pessoa que estava dentro de casa excluindo $\neg$ p desse EI. Ao excluir $\neg$ p do EI inicial da pessoa, o EI final (output) conterá apenas mundos p, denotando o estado em que a pessoa sabe que p não é mais apenas um potencial, mas é caso.

Sob a perspectiva dinâmica, von Fintel \& Gillies (2007) apresentam um modelo de semântica para o modal inglês de possibilidade might, que é sempre epistêmico. Nessa proposta, uma sentença modalizada testa o estado de informação inicial $i$, checando se a informação contida pela sentença prejacente é compatível com o estado de informação inicial. Se for, a sentença modalizada retorna o mesmo estado i como output. Se não for, o output é 0. Dessa forma, ao proferir uma sentença modalizada, o falante explicita seu EI:

Uma sentença como

(27) Pode estar chovendo.

é adequadamente proferida por um falante ignorante sobre o fato de estar ou não chovendo, desde que ele tenha alguma evidência de chuva. Logo, o falante explicita que seu EI contém p e $\neg$ p. Se seu EI contivesse apenas $\neg p$, ou seja, se o falante soubesse que não está chovendo, a sentença (27) seria semanticamente inaceitável. Essa observação corrobora a definição de possibilidade de Kratzer (1991), apresentada no capítulo anterior, segundo a qual uma sentença é possível se sua negação não for necessária. Se o falante sabe que não está chovendo (ele sabe $\neg$ p), logo a negação de p é uma necessidade, portanto p não é possível. 
Portner (2009) também mescla propostas formais com a semântica discursiva, em especial a noção de common ground (CG) ${ }^{17} \mathrm{de}$ Stalnaker (1975), que representa o conjunto de proposições mutuamente pressupostas. Para que não se confunda com pressuposição semântica, é importante esclarecer que, para Stalnaker (1975), proposições pressupostas são aquelas tidas como verdadeiras pelos participantes da conversa. Elas não são expressas pelas sentenças, mas constituem o conhecimento compartilhado. Entretanto, algumas sentenças proferidas não são aceitas para serem incluídas no $\mathrm{CG}$, como nos casos de discordância entre os conversadores. No diálogo entre A e B:
A: Onde está Mafalda?
B: Ela está em casa.
A: Não, não está. Acabei de ligar pra lá e o pai dela disse que ela saiu.

a sentença de B foi proferida, mas não aceita. Para Portner (2009) essa sentença entra no common propositional space (CPS), mas não no CG. O CPS inclui proposições de interesse dos conversadores e que são candidatas à inclusão no CG, ou seja, candidatas a serem compartilhadas como verdadeiras pelos conversadores. Se o falante A tivesse aceito a proposição expressa por B, ela entraria no CG. O CG é, então, um subconjunto do CPS. Portner formula assim a proposta para o modal inglês might:

Potencial de atualização de contexto de might: para qualquer sentença $\varphi$ da forma might- $\psi$, o CCP de $\varphi$ usada em um contexto c com base modal f e fonte de ordenação $g,[[\varphi]]^{\text {c,f,g }}$ é definido como: $<\mathrm{cg}, \operatorname{cps}>[[\varphi]]^{\mathrm{c}, \mathrm{f}, \mathrm{g}}=\left\langle\mathrm{cg}^{\prime}, \mathrm{cps}^{\prime}\right\rangle$ onde:
i) $\quad \mathrm{Cg}^{\prime}=\operatorname{cg} \cup\left\{[[\varphi]]^{\mathrm{c}, \mathrm{f,g}}\right\} \mathrm{e}$
ii) $\quad \operatorname{Cps}{ }^{\prime}=\operatorname{cps} \cup\left\{[[\psi]]^{\mathrm{c}, \mathrm{f}, \mathrm{g}}\right\} \cup\left\{[[\varphi]]^{\mathrm{c}, \mathrm{fg}}\right\}$
(Portner, 2009, p. 175) ${ }^{18}$

\footnotetext{
${ }^{17}$ Pagani, Negri e Ilari (2008) traduzem o termo que aparece em Chierchia (2008) como fundo conversacional compartilhado. Nesta dissertação, mantivemos o termo no original em inglês. 18 "Update potential for might: for any sentence $\varphi$ of the form might $\psi$, the update potential for $\varphi$ used in context $\mathrm{c}$ with modal base $\mathrm{f}$ and ordering source $\mathrm{g},[[\varphi]]^{\mathrm{c}, \mathrm{f}, \mathrm{g}}$ is defined as follows: $<\mathrm{cg}, \mathrm{cps}\rangle[[\varphi]]^{\mathrm{c}, \mathrm{f,g}}=\left\langle\mathrm{cg}^{\prime}, \mathrm{cps} \mathrm{s}^{\prime}\right\rangle$, where
}

i) $\quad \mathrm{Cg}^{\prime}=\operatorname{cg} \cup\left\{[[\varphi]]^{\mathrm{c}, \mathrm{fg}}\right\}$ and

ii) $\operatorname{Cps}^{\prime}=\operatorname{cps} \cup\left\{[[\psi]]^{\mathrm{c}, \mathrm{f}, \mathrm{g}}\right\} \cup\left\{[[\varphi]]^{\mathrm{c}, \mathrm{g} g}\right\}$ " 
A definição de Portner (2009) incorpora asserção e ato discursivo. A sentença modalizada $[[\varphi]]^{\mathrm{c}, \mathrm{f}, \mathrm{g}}$ é assertada ao ser adicionada ao CG. Ou seja, a partir dessa adição da sentença modalizada ao CG ela passa a ser uma proposição pressuposta, compartilhada como verdadeira pelos falantes. Se for uma sentença com modal de possibilidade, por exemplo, a possibilidade do evento descrito pela prejacente passa a ser verdadeira entre os conversadores. Aceita-se que esse ou aquele fato é possível. Além disso, há o ato de adicionar duas proposições ao CPS: a sentença não-modalizada $[[\psi]]^{\text {c,f,g }}$ e a sentença modalizada $[[\varphi]]^{\text {c,f,g }}$. Por exemplo, suponha uma situação em que o falante $\mathrm{A}$ e o falante $\mathrm{B}$ conversam sobre o paradeiro de Mafalda. O seguinte diálogo acontece na universidade:
A: Mafalda pode estar em casa.
B: Não, não pode. Ela mora do outro lado da cidade e acabei de vê-la chegando à universidade.

Ao proferir sua sentença, A inclui no CPS tanto a sentença modalizada 'Mafalda pode estar em casa' quanto a sentença 'Mafalda está em casa'. Ambas são sentenças candidatas a entrarem no $\mathrm{CG}$, ou seja, a serem compartilhadas pelos conversadores como verdadeiras, conforme Stalnaker. A prejacente é adicionada ao CPS, pois para que haja possibilidade é necessário que haja pelo menos um mundo $\mathrm{p}$ e que $\neg p$ não seja uma necessidade, ou seja, pode haver mundos $\neg$ p contanto que haja pelo menos um mundo p. Logo, ambas, tanto a modalizada quanto a não modalizada são candidatas ao CG. Entretanto uma verificação direta no mundo feita por B mostra que o mundo real é um mundo $\neg$, ou seja, exclui-se os mundos p do conjunto de evidências avaliadas pois $\neg$ p é necessariamente verdadeira. Logo, a sentença modalizada com o modal de possibilidade é rejeitada para o CG.

Agora, em outra situação, novamente os falantes discutem sobre o paradeiro de Mafalda e travam o seguinte diálogo:

(30) A: Mafalda pode estar em casa.

B: Sim, ela pode. Ontem ela ficou resfriada e hoje não veio à faculdade.

Nesse caso, novamente a sentença prejacente e a modalizada são incluídas no CPS. Mas dado que 'Mafalda não está em casa' não é uma necessidade, já que ela estar em casa é compatível com as evidências 
disponíveis para os falantes, a sentença modalizada foi aceita para ser incluída no CG e a possibilidade passa a ser compartilhada como verdadeira pelos conversadores. Ao mesmo tempo, a sentença prejacente 'Mafalda estar em casa' é adicionada ao CPS, pois, dado que a possibilidade de Mafalda estar em casa é pressuposta (inclusa no CG) e que falar que $\mathrm{p}$ é possível implica a factualidade de $\mathrm{p}$ (como veremos com mais detalhe no capítulo sobre implicaturas), é fácil intuir que a sentença p será adicionada ao CPS como candidata a ser incorporada ao CG. Captamos assim a ideia de que o falante, ao proferir pode-p, está inclinado a acreditar que p é o caso.

Portner (2009) também discute a diferença entre subjetividade e objetividade levantada pela análise subjetivista, para a qual a modalidade é um fenômeno atitudinal, não proposicional. A compreensão do conceito de subjetividade é, segundo Portner (2009), uma das contribuições da perspectiva funcionalista para a semântica das línguas naturais, principalmente por focar nos elementos nãoproposicionais, como atitude do falante e atos de fala. A discussão sobre a subjetividade envolve ainda a disponibilidade das informações nas quais o falante se baseia para proferir uma sentença modal, dentro de um contexto. Para alguns autores a diferença entre subjetividade e objetividade está no compartilhamento de informação (Nuyts e Papafragou, apud Portner, 2009), para outros está na qualidade da informação (Lyons, 1977).

Lyons (1977) coloca que algumas expressões modais epistêmicas são usadas para expressar a avaliação subjetiva do falante sobre uma proposição (modais subjetivos), enquanto outras expressam a probabilidade efetiva de a proposição ser verdadeira (modais objetivos). Segundo o autor, a interpretação de uma proposição modalizada muda conforme o tipo de conhecimento e o nível de comprometimento que o falante tem com a verdade da sentença prejacente. Como já dito, em sentenças objetivamente modalizadas o falante realiza um ato de descrição de uma circunstância baseado em evidências no mundo e a sentença pode ser aceita, questionada, concordada, etc., uma vez que as evidências podem ser checadas. Já em sentenças subjetivamente modalizadas o falante não pretende prioritariamente descrever o mundo, mas declarar sua opinião do que propriamente descrições de possibilidades. É o caso, por exemplo, da situação de polidez, quando chegamos à padaria e dizemos:

(31) Eu queria quatro pães. 
Ou na situação de conselho ou sugestão, em que Mafalda está mal por ter brigado com o namorado e alguém sugere:

(32) Ela podia pedir desculpas pro namorado.

Ou ainda da expressão do desejo, em que o falante está sofrendo com o mormaço e profere:

(33) Podia chover.

Nenhum desses significados pode ser expresso por 'pode'. Nesse sentido, desenha-se mais uma conclusão: 'podia' tem uma característica mais subjetiva, ausente em 'pode', ou seja, é mais adequado em contextos em que o falante não se compromete em descrever fatos conforme evidências disponíveis, mais em situações em que deseja se posicionar, dar uma opinião sobre a factualidade da prejacente. Dentro da discussão sobre objetividade e subjetividade, Portner (2009) observa que em contextos encaixados não ocorrem modais subjetivos, pois "a performatividade não pode vir encaixada". $\mathrm{Na}$ sentença

(34) Se Mafalda pode sair, eu também posso.

o 'pode' do antecedente não é interpretado como um ato de fala de permissão. E se receber uma leitura epistêmica, conforme a análise de Portner (2009) também não parece estar adicionando a possibilidade ao CPS. Intuitivamente, a possibilidade de Mafalda sair já tinha que estar no CSP para que o condicional fosse proferido.

No caso de 'podia', como já mostramos no capítulo anterior, apesar de ter leitura deôntica não é performativo, apenas relata uma permissão. Entretanto a intuição de Portner (2009) sobre não haver modais subjetivos em contextos encaixados parece correta também para 'podia':

(35) Se Mafalda podia sair, eu também podia.

Na sentença (35) o falante está falando de uma condição que existiu no passado, e o 'podia' encaixado na sentença não está veiculando um posicionamento do falante sobre a possibilidade de Mafalda sair. Na mesma forma que na sentença anterior, a possibilidade de Mafalda sair não está sendo adicionada ao CPS, pois intuitivamente 
ela já deve fazer parte do CPS para que a condicional seja proferida. Daí podemos depreender que 'podia', quando expressa passado real, perde seu traço subjetivo que apresenta em sentenças orientadas para o futuro (quando o morfema não expressa passado).

Portner (2009) aponta algumas direções que consideram a proposta na qual modais epistêmicos indicam o grau de comprometimento do falante com aquilo que ele diz. Quando o falante profere uma sentença modal- $\psi$ em um contexto em que $\psi$ é relevante, os participantes da conversa vão se preocupar em saber se $\psi$ deve ser ou não ser adicionada ao CG. A proposição modal também será adicionada ao CG, mas não é nisso que os participantes estão interessados: nesse caso, a proposição modal está dando informação sobre a atitude do falante em relação à proposição relevante $\psi$. Por exemplo, estamos em um contexto em que é verão, estamos de férias e queremos ir à praia. Mas o céu está nublado, e um de nós profere:

(36) Pode chover.

A sentença prejacente, 'chover', é relevante no contexto, e a possibilidade de chuva (sentença modalizada) é adicionada ao CG. O que é importante para os participantes da conversa, entretanto, é que o falante de (36) informa seu posicionamento sobre a possibilidade de chuva, de que essa possibilidade é real.

Ao analisar 'pode' e 'podia' em termos de objetividade e subjetividade, intuitivamente percebemos um traço mais subjetivo em 'podia'.

a. Mafalda pode sair.

b. Mafalda podia sair.

Como já mostramos, a expressão da possibilidade não é suficiente para diferenciar 'pode' de 'podia'. Mas é intuitivamente claro que, nas sentenças com 'pode', o falante veicula uma possibilidade mais "neutra" em relação à sua contraparte com 'podia'. Ambas as sentenças acima expressam que, baseado nas evidências que o falante tem, há pelo menos um mundo na base modal em que Mafalda sai. Entretanto a sentença (37.b), considerando o imperfeito com uso modal (passado falso), além de expressar essa possibilidade, também veicula intuitivamente que o falante tem menos convicção de que Mafalda vá mesmo sair. Além disso, dependendo do contexto, também veicula 
significados como polidez, exemplificado acima, conselho/sugestão ou desejo do falante.

Por exemplo, imagine um contexto em que Mafalda está muito envolvida com a sua dissertação e quase não sai de casa. Seus pais estão preocupados, pois ela está apática, com olheiras e solitária, muito diferente dos tempos em que encontrava sempre os amigos para sair e se divertir. Pensando no melhor para a filha, o pai profere:

(38) A Mafalda podia sair (pra espairecer, etc.)

Com a sentença acima além de expressar a possibilidade de Mafalda sair, e de expressar que o pai não acredita que ela vá sair (pois ela está muito envolvida com a dissertação), o pai também sugere que sair será bom para ela. É um mecanismo semelhante ao que acontece com a expressão de polidez, ou desejo.

As considerações sobre a análise subjetiva dos modais mostram que as diferentes abordagens não são excludentes, mas podem ser complementares. Para Portner (2009) a compreensão do conceito de subjetividade é uma das contribuições da perspectiva funcionalista para a semântica da língua natural, principalmente por focar nos elementos não-proposicionais, como atitude do falante e atos de fala. Essa visão pode ajudar, por exemplo, a explicar a natureza mais subjetiva de 'podia' em comparação com 'pode'.

Neste capítulo foram apresentadas algumas propostas que mesclam análises formais com análises discursivas para explicar, além da possibilidade semanticamente expressa por 'pode' e 'podia', também a subjetividade veiculada por essas expressões. Vimos que para usar uma sentença com 'pode' o falante precisa de evidências que respaldem a factualidade da prejacente e, por isso, 'pode' expressa uma possibilidade objetiva: o falante usa evidências que podem ser checadas para descrever uma situação no mundo. Ao contrário, ter evidência sobre a factualidade de $\mathrm{p}$ não é condição para que o falante use uma sentença com 'podia', logo, se o falante carece de evidências sobre a factualidade da prejacente, não é adequado que expresse uma descrição sobre uma situação no mundo. Por isso podemos dizer que 'podia' tem uma natureza mais subjetiva, ou seja, é adequado para situações em que o falante quer veicular seu posicionamento sobre a factualidade da prejacente. 


\section{IMPERFECTIVIDADE}

Aspecto e tempo verbal são duas categorias independentes, porém ambas relacionadas com o tempo, e comumente representadas no mesmo "domínio", o verbo. No PB, em muitos casos, a mesma flexão é responsável por representar tanto tempo quanto aspecto, o que torna mais difícil a distinção entre os dois (Ilari, 1997; Corôa, 2005; Pinker, 2007), e dificulta a análise de tempo e aspecto em separado. É o caso do imperfeito no $\mathrm{PB}^{19}$, exemplificado pela forma 'podia' analisada neste trabalho, que pode ou não expressar passado dependendo do contexto. A intenção deste capítulo é mostrar como o imperfeito atua na interpretação das sentenças modais no PB quando o morfema imperfectivo não expressa passado, ou seja, não desloca a possibilidade para um momento anterior ao momento de fala. Em especial, neste capítulo, vamos começar a analisar a relação do imperfeito com a veiculação do distanciamento do falante em relação à factualidade da prejacente, que já sugerimos ser uma das características de 'podia'. Acreditamos que a partir desse distanciamento é que se dá, entre outras interpretações, a veiculação da "contrafactualidade", a qual trataremos nas subseções 3.1 e 3.2 com base no trabalho de Iatridou (2000) sobre condicionais contrafactuais. Em seguida, na subseção 3.3 apresentaremos a análise de Ippolito (2004) sobre os condicionais imperfeitos. Apesar de tanto Iatridou (2000) quanto de Ippolito (2004) se voltarem a construções condicionais, o trabalho dessas autoras traz importantes contribuições para a análise de sentenças modalizadas com 'podia'. A reflexão sobre condicionais é também relevante se lembrarmos que Kratzer $(1981,2008)$ afirma que condicionais são modais.

Como já mencionado, 'pode' expressa uma possibilidade presente e 'podia' uma possibilidade passada ou presente, dependendo do contexto. Dadas as sentenças:

a. Mafalda pode viajar.

b. Mafalda podia viajar.

A sentença (39.a) expressa que, no momento de fala, Mafalda viajar no futuro (próximo ou não) é uma possibilidade. Tal sentença é

\footnotetext{
${ }^{19}$ Ter um morfema que codifique tempo e aspecto é uma característica encontrada em muitas línguas, entre elas as românicas e o grego.
} 
incapaz de expressar a possibilidade de que a viagem de Mafalda tenha ocorrido no passado, dada a agramaticalidade de (40):

(40) * Mafalda pode viajar ontem.

Para expressar passado do evento expresso pela prejacente é preciso utilizarmos o passado perfeito composto, como em:

(41) Mafalda pode ter viajado ontem.

Mas repare que o tempo passado é apenas da sentença prejacente; a possibilidade é ainda presente. A viagem de Mafalda, se ocorreu, ocorreu no dia anterior ao proferimento de (41).

Já 'podia' pode expressar uma possibilidade passada, conforme se verifica em (42):

(42) Mafalda podia viajar ontem.

Nesse caso, a possibilidade é passada e o falante pode inclusive saber que Mafalda não viajou. Nesse caso, ele veicula que houve a possibilidade de uma viagem que não ocorreu efetivamente.

Tanto sentenças com 'pode' como com 'podia' podem ser complementadas com advérbio de futuro, como mostram as sentenças em (43):
a. Mafalda pode viajar amanhã.
b. Mafalda podia viajar amanhã.

Ambas as sentenças expressam a possibilidade de Mafalda viajar amanhã, mas a contribuição semântica de 'pode' e 'podia' não é igual nas duas sentenças, embora em ambos os casos a possibilidade seja presente. A análise tradicional não capta essa diferença, que parece ser a seguinte: com (43.b) o falante expressa que embora a viagem seja uma possibilidade de ocorrer no dia seguinte ao do proferimento, ele não acredita que ela irá ocorrer ou ele não tem evidência para isso. Suponha que o falante precise que alguém viaje amanhã, mas ele não tem certeza de que Mafalda está disponível. Nessa situação, ele pode proferir (43.b), mas não pode proferir (43.a), porque com (43.a) ele expressa que tem evidências de que a viagem é viável. Por isso dissemos, no capítulo anterior, que com 'podia' o falante exprime uma 
opinião, é subjetivo, ao passo que com 'pode' ele expressa uma possibilidade objetiva.

$\mathrm{Na}$ introdução deste trabalho mostrou-se, com as sentenças repetidas abaixo, que o imperfeito pode expressar um hábito passado ou um evento passado em aberto no qual se inclui o momento de referência (a chegada de Lara):

(44) a. Mafalda tomava café todos os dias.

b. Mafalda dormia quando Susanita chegou.

As sentenças veiculam que Mafalda tinha, em um ponto anterior ao momento de fala, o hábito de tomar café todos os dias (44.a) e que a chegada de Susanita (momento de referência) está incluída no momento em que Mafalda dormia (momento do evento) e ambos são anteriores ao momento de fala. Há usos, entretanto, em que o morfema de imperfeito não codifica passado. Aproveitamos para já introduzir um exemplo com um verbo modal. Imagine que você está em um bar lotado, seus amigos chegam e a sua mesa não tem espaço suficiente para eles. Você então aponta para as pessoas da mesa ao lado e diz a um dos seus amigos:

(45) Eles podiam levantar e ir embora pra vocês sentarem.

Essa sentença não expressa que as pessoas da mesa tinham, antes do momento de fala (ou seja, no passado), o hábito de poder levantar e ir embora. E nem que há um momento antes do momento de fala de elas poderem levantar e ir embora. O que a sentença veicula, apesar da potencial expressão de passado do morfema '-ia', é que no momento de fala há a possibilidade de as pessoas levantarem e irem embora, apesar de o falante veicular sua falta de evidência sobre essa possibilidade e o seu desejo que isso ocorra.

O que esses exemplos têm em comum é que o imperfeito tem a função de "distanciar" ou "remover" o falante do momento e local em que ele se encontra (Ippolito, 2004), o que o torna intimamente relacionado com a função modal de "deslocamento" mencionada por von Fintel (2006). Segundo esse autor, uma sentença modalizada tem a propriedade de localizar a sentença prejacente no campo das possibilidades, deslocando nossa reflexão do aqui e agora para o possível. Junto com a temporalidade (tempo e aspecto), a modalidade constitui o cerne da propriedade do deslocamento das línguas naturais 
descrita por Charles Hockett (1960), que nos permite falar de situações que estão "além do aqui e agora".

Ippolito (2004) aponta três características principais do imperfeito nas diferentes línguas naturais: (i) a possível discordância entre o componente de passado do imperfeito e um eventual advérbio de tempo, (ex: 'Mafalda podia viajar amanhã'); (ii) o imperfeito tem um significado modal, pois a proposição expressa em uma sentença com imperfeito é avaliada de acordo com mundos possíveis que são, de alguma forma, compatíveis com o mundo real do falante; (iii) em sentenças com imperfeito, o falante não endossa a sentença, pois tem no máximo uma evidência indireta de que a sentença será o caso. Às vezes, não tem evidência nenhuma.

As características (ii) e (iii) são facilmente identificadas em (45): o falante está falando de mundos em que há uma possibilidade de as pessoas levantarem e saírem para dar lugar aos seus amigos e que, obviamente, não é o mundo real (ainda). Além disso, ele fala dessa possibilidade sem ter a mínima evidência de que as pessoas vão sair dali, por isso ele veicula sua opinião e desejo. São essas as duas características às quais será dada mais ênfase.

\subsection{CONTRAFACTUALIDADE}

Em sua proposta, Iatridou (2000) analisa os condicionais contrafactuais no grego moderno, os quais são construídos com verbos no imperfeito, como também parece ser o caso do português contemporâneo. Conforme a autora, a contrafactualidade se refere a construções gramaticais que expressam situações contrárias aos fatos. Isso significa que uma situação pode ser contrafactual ao presente ou ao passado, nunca ao futuro, já que o futuro ainda não é fato. A contrafactualidade pode, então, ser entendida como um tipo de nãofactualidade, já que também se refere a não-fatos, ou fatos em potencial. Neste trabalho, portanto, as situações que se referem ao futuro serão mais adequadamente chamadas de não-factuais, no sentido de que não se acredita que a sentença prejacente é ou se tornará necessariamente fato.

Seguindo a linha de Stalnaker (1975), Iatridou (2000) trata a contrafactualidade como uma implicatura conversacional, e mostra dois argumentos a favor disso. Primeiro, a contrafactualidade pode ser cancelada sem produzir contradição. $O$ exemplo de Stalnaker, reproduzido por Iatridou (2000) e traduzido aqui, é: 
(46) Se o paciente tivesse sarampo, ele teria exatamente os sintomas que tem agora. Nós concluímos, portanto, que o paciente tem sarampo.

O exemplo mostra que um condicional contrafactual é adequado em situações em que o falante acredita que o antecedente é verdadeiro (Iatridou, 2000, p.232). Argumentamos, na mesma direção, que uma sentença com 'podia' é adequada quando o falante não acredita que a prejacente é verdadeira, porém a contrafactualidade pode, como no condicional, ser cancelada, como podemos ver adiante:

(47) Mafalda podia estar em casa. E ela está mesmo.

O segundo argumento em favor de tratar a contrafactualidade como implicatura é que podemos assertar a falsidade do antecedente sem produzir redundância. O exemplo de Stalnaker, reproduzido por Iatridou (2000) foi adaptado aqui:

(48) Se o mordomo tivesse sido o assassino, nós teríamos encontrado sangue na faca. A faca estava limpa; portanto, o mordomo não foi o assassino.

Se a primeira sentença assertasse que o mordomo não foi o assassino, então a última sentença soaria mais como uma repetição de uma informação que já temos do que como uma conclusão, dadas as premissas. E não é isso o que ocorre. Uma sentença com 'podia' produz o mesmo efeito:

(49) Mafalda podia estar em casa agora, mas não está.

Não estamos repetindo uma informação. Logo, a sensação de que com 'podia' estamos expressando o que não é o caso é uma implicatura.

Iatridou (2000, p. 234) também mostra que a morfologia de passado nos condicionais pode não expressar passado. Os exemplos da autora são em inglês ${ }^{20}$, mas os exemplos em português mostram o mesmo fenômeno:

\footnotetext{
${ }^{20}$ No artigo de Iatridou (2000), correspondem a (47) os exemplos:

(5) If he had taken this syrup, he would have gotten better. (Iatridou, 2000, p. 233)

(7) If he takes this syrup, he will get better.

(8) If he took this syrup, he would get better.(Iatridou, 2000, p. 234)
} 
(50) a. Se ele tivesse tomado o xarope, ele teria/tinha ficado melhor.

b. Se ele tomar o xarope ele vai ficar melhor.

c. Se ele tomasse o xarope ele ficava/ficaria melhor.

A sentença (50.a) é um contrafactual passado, e veicula que a pessoa não tomou o xarope em algum ponto do passado. Já (50.b) e (50.c) se referem ao futuro, a algo que ainda pode ser realizado (ou seja, ainda é possível que ele venha a tomar o xarope), e por isso, conforme a definição de contrafactualidade assumida pela autora, não são contrafactuais. Tal característica se mostra pelo fato de que ambos aceitam como complemento um advérbio orientado para o futuro:

a. ?? Se ele tivesse tomado o xarope amanhã, ele teria ficado melhor.

b. Se ele tomar o xarope amanhã, ele vai ficar melhor.

c. Se ele tomasse o xarope amanhã, ele ficava/ficaria melhor.

Embora tanto (51.b) quanto (51.c) sejam orientados para o futuro, há entre elas a diferença morfológica. Para (51.c), onde a morfologia é de passado, a autora usa o termo future less vivid (futuro menos vívido), ou FLV. Para (51.b), em que a morfologia é de presente, a autora usa o termo future neutral vivid, ou FNV. Sendo ambos orientados para o futuro, a morfologia de passado em (51.c) não expressa passado, o que a autora chama então de fake tense (tempo falso). Como já mostramos, esse parece também ser os casos em que 'podia' não expressa uma possibilidade passada (anterior ao momento de fala $)^{21}$. Na leitura de passado falso, a sentença abaixo expressa que há a possibilidade no momento de fala de Mafalda viajar no dia posterior ao momento de fala:

(52) Mafalda podia viajar amanhã.

\footnotetext{
${ }^{21}$ Interessante notar que uma sentença com 'podia' pode servir como consequente de um condicional FLV, assim como uma sentença com 'pode' pode ser o consequente de um condicional FNV. Em PB, temos as seguintes construções:
}

(i) a. Se ele tomar o xarope, ele pode ficar melhor.

b. Se ele tomasse o xarope, ele podia ficar melhor.

c. * Se ele tomasse o xarope, ele pode ficar melhor. 
Nesse caso, a diferença entre a sentença acima e a mesma sentença com 'pode' é que na sentença com 'podia' o falante expressa sua falta de evidência de que Mafalda viajar amanhã se tornará fato. Nesse sentido, Iatridou (2000) coloca que no condicional FLV há a implicatura de que o mundo real é mais plausível de se tornar um mundo $\neg$ p do que um mundo p (Iatridou, 2000, p. 234) - no caso de (51.c) que é mais provável que ele não tome o xarope -, o que corrobora com a intuição captada em sentenças com 'podia':
a. Mafalda podia pagar a conta.
b. Mafalda podia estar em casa.
c. Mafalda devia estudar mais.
d. Mafalda devia ser solteira.

As sentenças acima veiculam que o falante acredita que Mafalda não vai pagar a conta, que ela não está em casa, que ela estuda pouco e que ela não é solteira no momento de fala. A morfologia de imperfeito nos modais provoca a interpretação de que, apesar de haver a possibilidade, o evento descrito pela prejacente não é ou não será um fato. As mesmas sentenças com 'pode' não veiculam a não-factualidade da prejacente, como mostram os exemplos; ao contrário expressam uma possibilidade real:
a. Mafalda pode pagar a conta.
b. Mafalda pode estar em casa.
c. Mafalda deve estudar mais.
d. Mafalda deve ser solteira.

A questão que surge nesse ponto é: se o morfema que deveria expressar passado não está expressando passado, qual será a função dele dadas as circunstâncias acima descritas? Iatridou (2000) propõe responder essa mesma pergunta para os condicionais com o fator de exclusão, que será detalhado a seguir.

\subsubsection{O fator de exclusão}

Para explicar a morfologia de passado falso em ambientes contrafactuais nos condicionais, Iatridou (2000) propõe que o elemento cuja realização fonética chamamos de morfema de imperfeito promove um significado do tipo: 


\section{$\mathrm{T}(\mathrm{x})$ exclui $\mathrm{C}(\mathrm{x})$}

A variável x pode se referir ao tempo, ou a mundos. T se refere a tempos ou mundos tópicos, ou seja, aqueles sobre os quais o falante está falando. $\mathrm{C}$ se refere ao tempo ou mundo do falante no momento de fala. Temos um passado real quando a variável $\mathrm{x}$ representa tempo e um passado falso quando a variável representa mundos. Aplicando essa proposta para o nosso problema, numa sentença com 'podia' orientada para o futuro, a variável se refere a mundos e é representada assim:

$$
\mathrm{T}(\mathrm{w}) \text { exclui } \mathrm{C}(\mathrm{w})
$$

Com base na fórmula acima, na sentença: Mafalda podia viajar.

os mundos tópicos, ou seja, os mundos sobre os quais o falante está falando (mundos em que Mafalda viaja) excluem o mundo real. Deveríamos dizer então que o morfema '-ia' atua excluindo o mundo real dos mundos sobre os quais o falante está falando, ou seja, o mundo real do falante é um mundo em que Mafalda não viaja.

A intuição por trás da semântica de exclusão proposta por Iatridou (2000) é boa, porém não discrimina o contexto contrafactual, em que o falante sabe que o fato descrito pela prejacente não é verdade, do contexto onde o falante é ignorante sobre a factualidade da prejacente, como nos casos orientados para o futuro. Nesse segundo caso, se o falante é ignorante sobre a factualidade de $\mathrm{p}$, ele não sabe se o mundo real é um mundo $\mathrm{p}$ e, portanto, não vai saber se deve ou não excluir o mundo real dos mundos tópicos. Em muitos casos, ele não quer excluir o mundo real dos mundos tópicos, como parece ser o caso da viagem de Mafalda descrita acima em que o falante precisa de alguém para viajar.

Eis outro caso. Imagine um contexto em que Mafalda tem pressa de pegar um ônibus para ir à universidade. Ela está em uma parte da cidade aonde não costuma ir e não conhece bem o itinerário dos ônibus naquela região. Tudo o que ela sabe é que na parada à qual ela está se dirigindo passa um ônibus com destino à universidade, mas ela não sabe o horário, nem a empresa. Assim que ela chega à parada, ela vê um ônibus vindo ao longe mas, sem conseguir enxergar o letreiro, não sabe se é o seu ônibus ou não. Mafalda então profere: 
(56) Aquele podia ser o meu ônibus!

Os mundos tópicos da sentença acima, ou seja, os mundos sobre os quais Mafalda está falando, são mundos em que aquele ônibus vindo ao longe é o seu ônibus. Mas note que ela não quer excluir o mundo real, ao contrário ela gostaria que o mundo real fosse um mundo em que aquele é o seu ônibus. Com (56), Mafalda expressa que, dado que ela sabe que naquele ponto passa o seu ônibus, há a possibilidade de aquele ônibus vindo ao longe ser o seu. Ou seja, Mafalda expressa que o mundo real pode fazer parte dos mundos em que aquele é o seu ônibus. Logo, Mafalda não está excluindo seu mundo real dos mundos tópicos, pois ela ainda não sabe se aquele é o seu ônibus ou não, ou seja, o mundo real está entre os tópicos.

A exclusão de mundos também não dá conta de explicar como podemos expressar gradualidade, ou seja, como expressamos que uma coisa é mais ou menos possível que outra. A proposta de Iatridou (2000) apenas dá conta do fato de o falante excluir o seu mundo real dos mundos tópicos, e com isso implica que o mundo real é mais plausível de se tornar um mundo $\neg$ p do que um mundo p. Nesse aspecto, a proposta das fontes de ordenação dada por Kratzer pode oferecer uma explicação melhor. No caso da sentença acima, além de não excluir seu mundo real dos mundos tópicos, há uma ordenação na base modal da sentença de Mafalda que coloca o mundo dela distante dos mundos ideais em que aquele é de fato o ônibus dela. $\mathrm{O}$ mundo real, portanto, não está excluído, mas sim afastado, porque ela veicula que ela não acredita que aquele é seu ônibus ou que ela não tem evidências para afirmar que aquele pode ser o seu ônibus.

Sendo assim, o máximo que o fator de exclusão de Iatridou (2000) explica é que o falante acredita que a proposição prejacente não vai ser o caso. A exclusão de mundos dos mundos tópicos não explica como veiculamos que os mundos excluídos são menos plausíveis.

\subsection{OS CONDICIONAIS IMPERFEITOS}

A proposta da exclusão dada por Iatridou (2000) corrobora o argumento de Stalnaker (1974) sobre condicionais, de que em condicionais contrafactuais o falante busca informação fora do common ground. Segundo Stalnaker (1975), o common ground é composto pelo conjunto de conhecimentos pressupostos pelos participantes de uma conversa, os quais se comprometem com a verdade das proposições que compõem esse conhecimento. Entretanto, em construções contrafactuais 
o falante pode falar sobre um fato que ele sabe não ser verdade, logo, nas palavras do autor, ele "suspende" as pressuposições buscando essa informação fora do $C G^{22}$.

Stalnaker também coloca que os condicionais contrafactuais são expressos por morfologia de subjuntivo. Assim, um condicional contrafactual tem a seguinte forma:

(57) Se ele tivesse tomado o xarope, ele teria ficado melhor.

Entretanto a morfologia de imperfeito (que é indicativa) aparece em condicionais contrafactuais no PB (e no grego como mostrou Iatridou). Por exemplo, numa situação em que Mafalda morreu, a sentença abaixo continua adequada:

(58) Se Mafalda estivesse viva, ela podia estar jantando conosco hoje.

Os condicionais indicativos, de acordo com Stalnaker (1975), são adequados apenas para contextos em que o condicional é compatível com as pressuposições do falante. Dessa forma, se faz parte do $C G$ que Mafalda morreu, a sentença abaixo é inadequada.

(59) \# (Mafalda morreu). Se Mafalda viajar amanhã, ela vai perder aula.

Contudo, como mostrou o exemplo (59), o imperfeito é indicativo e pode aparecer em sentenças condicionais não compatíveis com as pressuposições do falante. Da mesma forma, nas construções com 'podia' a pressuposição de que Mafalda morreu não impede o falante de proferir uma sentença com 'podia':

(60) (Mafalda morreu) Mafalda podia viajar amanhã ${ }^{23}$.

\footnotetext{
22 Esse "espaço" fora do common ground corresponde ao common propositional space proposto por Portner (2009) e discutido no capítulo 2, formado pelas proposições candidatas a serem incluídas no common ground. Sendo assim, Portner (2009) formaliza a ideia de Stalnaker.

${ }^{23}$ Nesse caso, pode-se pensar em supor a existência de um condicional implícito:

(i) (Se Mafalda não tivesse morrido) Mafalda podia viajar amanhã.

Mais adiante, há uma breve discussão sobre sentenças com 'podia' em consequentes de condicionais.
} 
Além disso, uma sentença com "podia' não necessariamente "suspende" as pressuposições do falante e veicula contrafactualidade como sugere Stalnaker (1975). Isso porque o falante pode ser ignorante sobre a factualidade da prejacente, ou seja, não sabe se a prejacente denota ou não um fato:

(61) Mafalda podia estar em casa, mas eu não sei se ela está ou não.

Nesse caso, quando o falante é ignorante sobre a factualidade da sentença, 'podia' apenas expressa a incerteza do falante de que Mafalda esteja em casa, além da possibilidade de ela estar em casa que, dado que o falante não sabe, continua aberta.

Ippolito (2004) propõe um terceiro tipo de condicional, o condicional imperfeito (no inglês, imperfect conditional, IC). A autora analisa o condicional imperfeito em italiano, mas que muito condiz com a intuição sobre o imperfeito no $\mathrm{PB}^{24}$. Segundo Ippolito (2004), os condicionais imperfeitos diferem dos indicativos e dos subjuntivos respectivamente pela flexibilidade temporal e pela "nãocancelabilidade" da implicatura de que o antecedente é falso. Quanto à implicatura de falsidade do antecedente nos condicionais imperfeitos, Ippolito (2004) mostra que essa implicatura resiste ao cancelamento, muito mais que nos condicionais subjuntivos. Os ICs são adequados apenas para contextos em que o falante acredita que proposição expressa pelo antecedente é falsa. É a mesma intuição captada por Iatridou (2000) e que temos com sentenças modalizadas por 'podia' de que o falante implica que o mundo real tende a ser um mundo $\neg$ p. Ippolito (2004) argumenta que o significado de que o falante acredita que $\neg$ p deve ser derivado, via implicatura griceana, da ignorância do falante sobre $\mathrm{p}, \mathrm{ou}$ seja, o falante não sabe se o mundo real é um mundo p ou $\neg$ p.

Já a flexibilidade temporal permite que os ICs sejam modificados por advérbios de tempo. O exemplo da autora é:

(62) Se arrivavi ieri/domani, incontravi mia sorella.

'Se chegava- $2 p$ ontem/amanhã, encontrava- $2 p$ minha irmã.'

24 Pelo trabalho de Ippolito se depreende que as formas de imperfeto (imperfeito) e condizionale (que corresponde ao futuro do pretérito) estão em variação e o imperfeto é predominante, assim como no $\mathrm{PB}$, como mostram pesquisas em sociolinguística, entre elas da Silva (1998), Costa (1997) e Karan (2000) 
Sentenças com 'podia' também podem ser modificadas por advérbios de tempo, tanto de passado quanto de futuro, como já vimos. Já sentenças com 'pode' só aceitam advérbios de futuro:

a. Mafalda podia viajar amanhã/ontem.

b. Mafalda pode viajar amanhã/*ontem.

A autora argumenta que essa flexibilidade temporal das construções com imperfeitos se deve ao fato de que o componente passado da morfologia de imperfeito deslocar o momento de avaliação para algum tempo passado saliente no contexto. Nesse aspecto ela compara os imperfeitos com os indicativos clássicos, nos quais, como não apresentam morfologia de imperfeito, esse deslocamento temporal não acontece. O momento de avaliação nos condicionais indicativos coincide necessariamente com o momento de fala.

Pela análise intuitiva de sentenças com 'podia' no PB percebese que a proposta de Ippolito (2004) se aplica quando o tempo do modal imperfectivo é real, ou seja, quando o morfema '-ia' expressa realmente passado (o tempo do falante é excluído do tempo tópico, conforme Iatridou (2000)). Quando a sentença:

(64) Mafalda podia viajar amanhã.

expressa uma possibilidade passada de Mafalda viajar amanhã, podemos interpretar 'podia' como deslocando a perspectiva de avaliação para o passado. Entretanto, a análise da autora não contempla casos em que a interpretação da sentença tem a perspectiva presente e orientação futura, como é o caso das sentenças que estamos analisando aqui. Quando com a sentença acima o falante quer expressar que há uma possibilidade presente de Mafalda viajar amanhã, não se aplica dizer que o imperfeito está funcionando como um deslocador de perspectiva, pois o momento de avaliação coincide com o momento de fala e essa condição, segundo Ippolito (2004), é a condição para os condicionais indicativos.

Dado que os imperfeitos compartilham o mesmo modo com os indicativos, a conclusão de que os imperfeitos tenham características de indicativos não vem a ser um grande problema. A princípio a análise de Ippolito (2002) não pode ser considerada incompleta para o $\mathrm{PB}$, isso porque a autora analisa os condicionais, em que os verbos imperfeitos vêm encaixados. Nesse trabalho estamos analisando sentenças com 
'podia' não encaixadas, em que o imperfectivo pode ser ambíguo entre expressão de tempo/aspecto e expressão de modalidade.

Dado que nossa hipótese é que o imperfeito é o principal responsável pelas diferenças entre 'pode' e 'podia', neste capítulo apresentamos algumas análises sobre a atuação do imperfeito em sentenças modais. Vimos, conforme Iatridou (2000) e Ippolito (2004) que o imperfeito pode expressar temporalidade (passado real) ou modalidade (passado falso), e, no segundo caso, no qual focamos nessa dissertação, a relação do imperfeito com a expressão da nãofactualidade, característica captada intuitivamente e prevista pelas autoras. Vimos também que a proposta de Iatridou (2000), de que em contrafactuais o falante exclui o mundo real dos mundos tópicos (veiculando assim que o mundo real é um mundo $\neg$ p) traz uma intuição correta, porém insuficiente ara explicar os casos em que o falante é ignorante sobre a factualidade da prejacente. A ideia é que se o falante não sabe como é o mundo real, ele não saberá se o mundo real deve ser excluído ou não dos tópicos. Este capítulo também serviu para introduzir o assunto da relação do imperfeito com o "distanciamento" do falante em relação à factualidade da prejacente, a partir do que se dá a veiculação de não-factualidade. 


\section{ALÉM DA POSSIBILIDADE}

Embora semanticamente tanto 'pode' quanto 'podia' expressem possibilidade, ou seja, a prejacente p é possível sob a condição de que $\neg$ p não seja necessária, há, como já vimos, significados veiculados por 'podia' e não por 'pode', como não-factualidade e desejo, que constituem a diferença entre ambos. $\mathrm{O}$ intuito deste capítulo é apresentar esses significados e tratá-los como implicaturas conversacionais, pois, como veremos, são canceláveis e reforçáveis assim como as implicaturas descritas por Grice (1975). A proposta a ser apresentada será de que as implicaturas podem ser derivadas de operações formais, a partir de violações das máximas conversacionais. A ideia a ser defendida é que a presença ou não do morfema de imperfeito é o principal responsável pela veiculação desses significados.

Semanticamente, a forma presente 'pode, que pode ser interpretada como tendo um morfema nulo, (em comparação com a presença do morfema '-ia' em 'podia') restringe os mundos da base modal àqueles mais semelhantes ao mundo real - ou seja, o presente é um operador que toma um conjunto de mundos e retorna um conjunto de mundos - tipo $\langle s, t\rangle,\langle s, t\rangle-$ e a operação exclui do conjunto de mundos iniciais os mundos que não são semelhantes ao mundo real. A base modal é composta, portanto, apenas de mundos que são próximos ao mundo real. A fonte de ordenação irá então organizar esses mundos de acordo com a normalidade. O modal afirma que entre os mundos mais próximos dos ideais há pelo menos um em que $\mathrm{p}$ é verdadeira. Já o morfema '-ia', ao contrário, toma um conjunto de mundos e retorna o mesmo conjunto de mundos, não promovendo nenhuma restrição de mundos. Logo, a base modal contém mundos de todos os modos, sejam os mais próximos ou os mais distantes do real. Dado que o falante não tem evidências, a fonte de ordenação será vazia, retornando os mundos sem organizá-los, já que não há como saber quais são os mundos mais próximos da normalidade. Só sabemos que nesse espaço irrestrito de mundos, há um em que p é verdadeira.

\section{1 (NÃO-) FACTUALIDADE}

Umas das diferenças intuitivamente captadas entre sentenças com 'pode' e 'podia' é que sentenças com 'podia' veiculam a nãofactualidade da proposição prejacente, porque o falante não tem evidências para isso ou veiculam que o falante tem evidências contrárias 
e portanto não acredita na factualidade da prejacente. Voltando ao exemplo (23) no capítulo 1, sobre a possibilidade de chuva:
a. Pode chover logo.
b. Podia chover logo.

A sentença (65.b) pode ser usada com felicidade independente de haver evidências de chuva, porque o morfema afirma que há um mundo em que chove, sem qualquer restrição na base modal. Logo, chover é uma possibilidade trivial. Por que então proferir uma sentença sobre a possibilidade de chover? Qual seria a relevância de falar sobre uma trivialidade? Porque o falante que profere tais sentenças não só expressa possibilidade de chuva (porque a negação da prejacente 'Não chove' não é uma necessidade, ou seja, há pelo menos um mundo da base modal em que chove) como também implica que a prejacente será fato com (65.a) e implica que a prejacente não será fato com (65.b). Isso porque a sentença (65.a), com 'pode', restringe os mundos da base modal àqueles mais semelhantes ao real, ou seja, àqueles que se assemelham ao real dado o que se sabe sobre a normalidade dos eventos no mundo real. Essa restrição indica que o falante tem evidências à favor da factualidade de $\mathrm{p}$, evidências que respaldam a tendência de o mundo real ser um mundo p. Por exemplo, o falante pode estar observando as nuvens escuras no céus, os trovões cada ver mais fortes e a ventania intensa. Dado que o falante sabe que essas são as condições normais para chuva, sua "aposta" na possibilidade de chuva é mais precisa, e assim, profere (65.a). Já com (65.b) o falante veicula que não vai chover pois lhe falta evidência que indique a factualidade de p. Por exemplo, está um dia quente, de muito mormaço, e o falante está sofrendo com o calor. Não há evidência de chuva, mas também não há evidência de que não vá chover (como céu limpo, muito sol, etc.). Assim, o falante profere (65.b) pois dada a normalidade do mundo real, se o clima continuar como está, não vai chover, ou seja, o mundo real tende a ser $\neg$ p. Por essa razão o falante expressa uma possibilidade não restrita àquela ancorada na normalidade do mundo real, e profere uma sentença com 'podia', em que inclui na sua base de avaliação também os mundos mais distantes ao mundo real, ou seja, tanto os mundos em que chove, que estão mais próximos do real, quanto os mundos em que não chove, ou seja, os mais distantes do real. Considerando que nessa imensidão de mundos deve haver ao menos um em que chove, a possibilidade de chuva expressa por (65.b) se torna trivial. 
Falar sobre uma coisa na qual não se acredita ou não se tem evidência, segundo Grice (1975), é ferir o Princípio de Cooperação pois quebra a máxima "só diga aquilo que acredita ser verdade" que compõe a categoria da Qualidade. Uma quebra de máxima desencadeia implicaturas: se o falante deliberadamente não quer ser cooperativo, é porque ele tem algo mais a expressar. No caso de sentenças com 'podia', o falante expressa que gostaria que o mundo real fosse um mundo p. Por exemplo, imagine que faz um dia de muito calor, sem nuvens e muito sol. Não há evidência nenhuma de que possa chover. Entretanto, a sentença em (66.b) é bem adequada à situação, enquanto a não é:

$$
\begin{aligned}
& \text { a. \# Pode chover. } \\
& \text { b. Podia chover. }
\end{aligned}
$$

Dado um contexto em que o falante não vê evidência nenhuma de que vá chover, está sofrendo com o calor, ou que esteja chateado por ter que trabalhar e não poder aproveitar o dia para ir à praia, o falante expressa adequadamente (66.b) nessa situação, mesmo sem evidência nenhuma de chuva. Note que a sentença (66.a), quando complementada por uma negativa, soa paradoxal :

(66') a. Pode chover, mas não vai.

b. Podia chover, mas não vai.

O paradoxo de (66'.a) deriva justamente de que o falante expressa que há uma possibilidade objetiva de chuva, implicando que acredita nessa possibilidade pelo fato de possuir evidências para acreditar nisso, e logo em seguida afirma que não vai chover. Já a sentença (66'.b), com o mesmo complemento, não soa paradoxal. A adequação de (66'.b) se deve a que a crença veiculada pelo falante é compatível nas duas partes da sentença: na primeira parte, o falante expressa a possibilidade de chuva e, devido ao imperfeito que mantém a base modal irrestrita por causa da falta de evidência do falante, implica, na situação dada, que não vai realmente chover. Logo em seguida, o falante afirma que não vai chover, reforçando que não vai chover.

As sentenças acima podem também ter complementos positivos. Considerando os três pontos como representando um intervalo de tempo para checagem de informação no mundo, temos:

(66') a. Pode chover (...) e vai chover mesmo.

b. Podia chover (...) e vai chover mesmo 
A não-factualidade veiculada pelo morfema de imperfeito já foi prevista por Iatridou (2000) na sua proposta de uma semântica de exclusão, a qual descartamos no capítulo 3 com o exemplo do ônibus de Mafalda, mostrando que o mundo real pode ser um dos mundos tópicos, o que contradiz a proposta da autora. Na proposta de Iatridou (2000), quando o morfema de imperfeito não denota passado real ele promove uma exclusão de mundos: o falante exclui o mundo real dos mundos tópicos (dos quais ele está falando) e implica que o mundo real tende a ser um mundo $\neg$ p. Entretanto, como já havíamos dito, essa proposta não dá conta de explicar contextos em que o falante é ignorante sobre a factualidade da prejacente, ou seja, quando ele não sabe se o mundo real é ou não um mundo $\mathrm{p}$, e, portanto, não sabe se o mundo real está entre os tópicos ou não. Além disso, não explica como expressamos graus de possibilidade.

A proposta que vamos apresentar aqui é que a não-factualidade e o desejo podem ser derivados de operações formais, mas, em vez de exclusão, vamos defender a ideia de que a semântica do morfema de imperfeito é de identidade, ele retorna o mesmo conjunto de mundos, logo não há uma restrição de mundos àqueles mais semelhantes ao mundo real. Por isso não há também uma fonte de ordenação. Assim, embora 'pode' e 'podia' expressem possibilidade, o presente em 'pode' restringe os mundos da base modal aos mundos mais semelhantes ao mundo real, o que torna p mais provável, pois o conjunto é mais restrito. Ao utilizar 'pode', o falante deixa claro que dispõe de evidências objetivas a favor de que chova. Por exemplo, está trovejando, ventando, há nuvens carregadas e escuras no céu, e o falante viu na TV alguma previsão do tempo que indicava chuva. Assim, quando o falante profere 'Pode chover' o que ele expressa é que, dado um conjunto de mundos restrito àqueles mais semelhantes às evidências que ele tem do mundo real, com base no que se sabe sobre a normalidade, há pelo menos um mundo em que chove. As evidências respaldam a escolha do falante em proferir 'pode' ao invés de 'podia'.

Suponha que haja 4 mundos, entre eles o mundo real. Desses mundos apenas no mundo real w e em outro mundo w' as evidências são as mesmas. O presente exclui os outros mundos e a base modal está restrita a w e a w'. Como 'Não vai chover' não pode ser uma necessidade, há pelo menos um mundo em que chove. Veja que nesse caso, por causa da restrição, trata-se de uma possibilidade plausível, objetiva. 
Essas evidências não são necessárias para que o falante expresse uma sentença com 'podia'. Numa situação em que o falante não sabe nada sobre chover ou não, apenas sofre com o tempo abafado, ele profere 'podia chover'. Dado que ele não tem evidência sobre a chuva, não tem respaldo dessas evidências para restringir os mundos da base modal àqueles mais semelhantes ao real. Como já dissemos, o falante pode também usar 'podia' se as evidências são contrárias aos fatos. Assim, ao usar 'podia' ele mostra que ou não tem evidências ou tem evidências contrárias, porque com 'podia' ele mantém a base modal "ampla", contendo tanto mundos semelhantes quanto os mais diferentes do mundo real. Por exemplo, se temos 4 mundos, o morfema '-ia' nos retorna os mesmos 4 mundos, mostrando que a falta de evidência impede que o falante seja mais preciso e os restrinja. Ele deve admitir todos os mundos para poder afirmar que chover é possível. Nesse caso, tudo o que o falante expressa é a possibilidade trivial: no conjunto de mundos não restritos, há pelo menos um em que chove. Veja que ao veicular que não tem evidências, a possibilidade se torna trivial, já que garantimos que 'Não chove' não é uma necessidade.

Assim, com esse raciocínio, o falante é pouco informativo, já que na amplitude de mundos da base modal é intuitivo que haja pelo menos um em que chova. Contraste essa situação com a sentença:

\section{(68) É pouco provável que chova.}

Com essa sentença o falante veicula que tem evidências que indicam que a possibilidade de chuva é pouca, e não que não tem evidência nenhuma de chuva, como no caso de 'podia'. No caso de (66.b), o falante simplesmente não tem evidência alguma e expressa uma possibilidade trivial. Com isso o falante veicula que não tem evidências para fazer, digamos, uma aposta mais precisa sobre como é o mundo real, pois ele pode ser tanto semelhante a mundos p quanto a mundos $\neg$ p, dado a falta de evidência do falante. Sem o respaldo das evidências, $o$ falante não se compromete em expressar uma possibilidade mais "forte" usando uma sentença com 'pode', que restringe a base a mundos próximos ao mundo real e os organiza segundo uma fonte de ordenação de normalidade.

Dessa análise chegamos à conclusão prevista no capítulo 2 , de que 'pode' tem um traço mais objetivo e 'podia' um traço mais subjetivo. Para proferir uma sentença com 'pode' o falante restringe os mundos e para isso precisa de mais evidências no mundo que respaldem essa "aposta" de que o mundo real é um mundo p. Essas evidências 
podem ser checadas, questionadas e refutadas, assim como analisa Lyons (1977) sobre os modais objetivos ou, como analisa Portner (2009), podem ser aceitas ou não para serem incluídas no $C G$. Por outro lado, para proferir uma sentença com 'podia', o falante não precisa de evidência nenhuma que respalde a possibilidade objetiva. Como mostra o exemplo da chuva, o falante pode não ter evidência nenhuma e, mais ainda pode ter evidências contrárias à chuva. Mesmo assim, 'Podia chover' é adequada nessa situação. Essa situação nos remete à análise de Lyons (1977) em que o autor coloca que modais subjetivos expressam mais declarações de opinião. No caso de não haver evidência de chuva, mas o falante estar sofrendo com o calor, ele declara que, em sua opinião, dadas as circunstâncias, chover seria bom.

\subsection{DESEJO}

A interpretação de desejo é mais evidente em contextos contrafactuais, em que o falante sabe que a sentença prejacente não é fato ou em que as evidências são contrárias ao que a prejacente expressa. Imagine a situação em que o falante vê Mafalda, se interessa por ela, mas sabe que ela é casada. $\mathrm{O}$ falante profere:

(69) Mafalda podia ser solteira.

Nesse caso, o falante está claramente falando sobre um conjunto de mundos dos quais ele sabe que o mundo real não faz parte, expressando um contrafactual. Nesse caso, por que o falante violaria a máxima da qualidade, expressando algo que ele sabe que é falso? Porque ele quer expressar seu desejo. Assim, para um falante do PB, a sentença (69) expressa algo a mais. Imagine que o falante é apaixonado por Mafalda, com (69) ele também expressa algo como "Eu gostaria, ou é conveniente para mim que Mafalda seja solteira". Ou seja, o falante veicula seu desejo de que Mafalda seja solteira.

Entretanto essa interpretação de desejo se mantém também quando o falante é ignorante sobre o estado civil de Mafalda, ou seja, não sabe nada que indique seu estado civil. Imagine que, nesse contexto, o falante vê Mafalda na rua e fica interessado por ela. Ele vê que Mafalda é bonita e simpática, dado o estereótipo de que moças bonitas como ela arrumam namorado mais facilmente, o falante tende a acreditar que ela não seja solteira. Mas além do estereótipo, ele não tem mais nenhuma evidência que respalde expressar uma possibilidade mais objetiva: ele não tem evidência nenhuma sobre a factualidade da 
prejacente, ou seja, não sabe nada que o leve a crer que ela seja solteira. Apesar disso, ele adequadamente profere a sentença (69). Mesmo assim, intuitivamente captamos o desejo do falante de que Mafalda seja solteira. A pergunta que emerge é por que o falante fala de uma possibilidade sobre a qual ele não tem evidência? Por que ele expressa semanticamente uma possibilidade trivial, deixando claro que não tem evidências que a sustentem? Nesse contexto, dado que o falante se interessou romanticamente por Mafalda, ele quer expressar que deseja que Mafalda esteja disponível para namorar.

Como já mencionado no capítulo 2, uma possível explicação para a expressão de desejo com 'podia' seria a fonte de ordenação bulética. Porém esse caminho traz problemas para a análise de 'podia' como expressão de possibilidade. Com outras fontes de ordenação 'podia' expressa possibilidade, ou seja, há pelo menos um mundo em que $\mathrm{p}$ é o caso, ou seja, não-p não é uma necessidade. Se pensarmos sobre a interpretação da sentença (69) levando em conta uma interpretação de desejo, teríamos que em todos os mundos compatíveis com o desejo do falante, Mafalda é solteira. $\mathrm{Na}$ ordenação bulética, uma vez que os mundos ideais são aqueles em que os desejos do falante são satisfeitos, a fonte ordena os mundos de modo que todos sejam compatíveis com o desejo do falante, ou seja, em todos os mundos mais próximos dos ideais os desejos são satisfeitos. Mas se 'podia' ainda expressar possibilidade, a interpretação de (69) seria: há pelo menos um mundo p nos mundos compatíveis com os desejos do falante. Vimos, entretanto, que não é essa a interpretação de (69). Por outro lado, adotar que 'podia' expressa em todos os mundos compatíveis com o desejo do falante é criar um impasse para a semântica de 'podia', porque ele expressaria possibilidade nas ordenações deôntica, teleológica e estereotípica, mas expressaria necessidade na ordenação bulética. Além disso, caso a expressão do desejo fosse uma operação formal, não poderia ser cancelada e, como mostraremos mais adiante neste capítulo, é possível proferir uma sentença com 'podia' sem o traço de desejo. Com esse resultado, seríamos forçados a dizer que 'podia' é ambíguo entre possibilidade e necessidade, o que vai contra as propostas teóricas em que nos baseamos e contra a nossa própria intuição. Portanto a análise da expressão de desejo como fonte de ordenação parece não ser a mais adequada.

Outra forma de tratar esse problema seria considerar que o morfema de imperfectivo promove uma segunda fonte de ordenação, como propõe von Fintel e Iatridou (2008). No caso de 'podia', poderíamos dizer que além da fonte estereotípica o morfema '-ia' induz 
a ordenação bulética. Entretanto não é claro como essa proposta pode ser aplicada a modais de possibilidade no PB. O que ocorreria é que 'podia' toma a base modal irrestrita, conforme propomos aqui, e expressa que há pelo menos um mundo dentro dessa base modal em que a prejacente é o caso, e então a fonte bulética reorganizaria esses mundos conforme os desejos do falante. Ou seja, segundo a fonte de ordenação bulética, em que os mundos ideais são aqueles em que o desejo é satisfeito, em todos os mundos próximos a eles p é o caso. Entretanto essa proposta não resolve o problema, pois 'podia' continuaria expressando possibilidade, mas expressaria necessidade na fonte bulética. E ainda, como acontece no caso da fonte de ordenação bulética descrita acima, a expressão de desejo não poderia ser cancelada.

$\mathrm{O}$ fato é que a interpretação de desejo, assim como a da nãofactualidade, pode ser cancelada e reforçada:

(70) a. Podia chover, mas eu não quero que chova.

b. Podia chover, eu quero muito que chova.

A razão para (70.a) ser aceitável é a mesma vista para (66.b’): as duas partes da sentença são compatíveis com a indisposição do falante em aceitar a verdade de $\mathrm{p}$, seja por falta de evidência, seja por não desejar que o mundo real se torne um mundo p. Assim, a expressão de desejo é cancelada. No caso de (70.b), por outro lado, na primeira parte da sentença o falante, como em (70.a), expressa a possibilidade e veicula sua falta de evidência sobre a factualidade da prejacente: assim, se o falante expressa algo que ele acredita não ser verdadeiro (pois, nesse caso, lhe falta evidência), ele veicula outros significados, sendo o desejo de que o mundo real seja um mundo p um bom candidato.

Como já mostramos, a expressão do desejo é mais proeminente em situações contrafactuais, aquelas em que o falante sabe que a prejacente não é ou será possível, mas se mantém mesmo que o falante seja ignorante sobre a factualidade de p. De qualquer forma, tanto nos casos de contrafactualidade como nos casos de não-factualidade, quando o falante fala sobre algo que ele acredita não ser (ou que não será) verdade ou para o qual ele não tem evidência, ele está quebrando a primeira máxima da Qualidade de Grice. Se o falante é cooperativo e está conscientemente quebrando uma máxima conversacional, significa que ele quer expressar outra coisa. No caso do desejo, se o falante sabe que p não é possível, como em (69), ou se ele sabe que p é uma possibilidade, mas não acredita nela, o falante pode estar querendo expressar seu desejo de que $\mathrm{p}$ fosse ou venha a ser verdade, ou porque 
acredita que p seja a melhor alternativa, como no caso da expressão de sugestão ou conselho. 


\section{CONSIDERAÇÕES FINAIS}

O objetivo deste trabalho foi descrever e explicar as semelhanças e diferenças entre 'pode' e 'podia' quando ambos expressam uma possibilidade a partir do momento de fala no PB, isto é, quando 'podia' expressa passado falso e o evento descrito pela prejacente é orientado para o futuro. Seguimos a hipótese de que a responsável pelas diferenças entre ambos é a atuação do imperfeito, presente em 'podia' mas ausente em 'pode'. Enquanto a possibilidade semântica é o significado comum entre ambos, expresso pelo radical 'pod-', comum a ambos, suas diferenças são de ordem pragmática, como a expressão de não-factualidade, desejo, sugestão e polidez veiculadas por 'podia' e não por 'pode'. O radical comum indica, seguindo a semântica proposta por Kratzer (1991), que não-p não é uma necessidade. A proposta esboçada aqui é que 'pode' restringe os mundos da base modal àqueles mais próximos ao mundo real dado um parâmetro de ordenação, o que expressa uma possibilidade mais objetiva e implica factualidade. Já 'podia' retorna uma base modal irrestrita, tanto com mundos próximos quanto distantes do real, mostrando que o falante tem pouca evidência sobre a factualidade da prejacente e com isso veiculando não-factualidade.

Com base na proposta de Kratzer (1981, 1991, 2008, 2010), mostramos que tanto 'pode' quanto 'podia' expressam possibilidade, ou seja, a proposição encaixada em 'pode' ou 'podia' é possível em w se, e somente se, a sua negação $\neg$ p não for uma necessidade em w. Também mostramos, através da análise dos exemplos, que tanto 'pode' quanto 'podia' são compatíveis tanto com a base modal epistêmica quanto com a base modal de raiz, e que, então, a compatibilidade com as bases modais não constitui uma explicação para a diferença entre ambos. Mostramos também que 'pode' e 'podia' se combinam com as fontes de ordenação estereotípica, teleológica e deôntica. Já a fonte bulética, que poderia ser a saída para explicar porquê 'podia' veicula desejo e 'pode' não, do que poderíamos concluir que 'pode' não combina com a fonte bulética enquanto 'podia' combina, não consideramos adequada, já que a interpretação de desejo pode ser cancelada, indicando que essa interpretação é fruto de uma implicatura. Caso a expressão de desejo fosse semântica, como seria se fosse resultado de uma ordenação, ela não poderia ser cancelada.

Recorremos a propostas mistas para explicar a posição subjetiva do falante veiculada tanto por 'pode' quanto por 'podia'. Trabalhamos especialmente com Lyons (1977), para quem modais subjetivos são mais 
para declarações de opinião e não descrições de mundo, e Portner (2009), que propõe o common propositional space (CPS), um superconjunto do common ground (CG) onde o falante inclui proposições candidatas a serem incluídas no $\mathrm{CG}$, ou seja, a serem compartilhadas como verdadeiras pelos participantes da conversa (Stalnaker, 1975). Essa operação é semântico-discursiva, dado que essas candidatas ao CG podem ser rejeitadas, e não serem incluídas. Dessa análise depreendemos que quando o falante carece de evidências que respaldem sua "aposta" na factualidade da prejacente $p$, ele utiliza 'podia' (não restringe os mundos àqueles mais semelhantes ao real) e adiciona a sentença modalizada 'podia-p' ao CG e tanto prejacente $\mathrm{p}$ quanto a negação da prejacente $\neg$ p ao CPS. A ideia de ele também adicionar $\neg$ p ao CPS como candidata a ser incluída no CG vem por ele não ter evidência que respalde a factualidade do evento denotado por $\mathrm{p}$. Já para utilizar 'pode' o falante precisa de evidências que indiquem que o mundo tende a ser um mundo p. Por isso, ao usar 'pode' o falante acrescenta ao CPS tanto a modalizada 'pode-p' quanto a prejacente $\mathrm{p}$, pois, dadas as evidência que possui, o falante acredita que p é uma boa candidata a ser incluída no CG, não incluindo no CPS a negação da prejacente. Dado que o falante não precisa ter evidências no mundo que indiquem a factualidade de $\mathrm{p}$ para usar 'podia', e ao contrário, precisa dessas evidências para usar 'pode', observamos que 'podia' tem uma característica mais subjetiva que 'pode', ou seja, enquanto 'podia' é adequado para veicular declarações de opinião, que não necessitam de evidências que possam ser checadas e questionadas, 'pode' expressa uma possibilidade mais objetiva, a descrição de uma situação no mundo.

A hipótese defendida foi que os significados que diferenciam 'pode' e 'podia', como a veiculação de não-factualidade da prejacente, o desejo, sugestão e polidez, são de natureza não proposicional, ou seja, são significados pragmáticos, mas que podem ser derivados de operações formais. No capítulo 3, argumentamos que o que ocorre na veiculação de não-factualidade da prejacente em 'podia' não é exclusão de mundos como propõe Iatridou (2000). Segundo ela, com o imperfeito o falante exclui o mundo real dos mundos tópicos (aqueles sobre os quais ele está falando), mas essa proposta não explicaria as situações em que o falante não sabe se o mundo real é p ou $\neg$ p, ou seja, o mundo real pode ou não estar entre os tópicos. Como mostramos, há situações discursivas em que o falante quer efetivamente incluir o mundo real entre os mundos tópicos.

A partir da discussão construída nos três primeiros capítulos, a proposta que apresentamos foi que em vez de exclusão (Iatridou, 2000) 
há uma não restrição de mundos. O morfema nulo em 'pode' (em comparação com a presença do morfema '-ia' em 'podia') restringe os mundos da base modal àqueles mais semelhantes as mundo real conforme o que se sabe sobre o mundo real. A fonte de ordenação, então, organiza esses mundos conforme a normalidade, sendo os mundos ideais os chamados inerciais, isto é aqueles em que os eventos ocorrem sem acidentes. Por exemplo, quando o falante profere 'Pode chover', ele avalia os mundos em que, conforme a normalidade dos eventos do mundo real, chove. Isso ocorre porque o falante tem evidências que indicam uma possibilidade objetiva de chuva, por exemplo, ele observa que as condições do tempo indicam chuva. Com esses mundos restritos, o falante tem respaldo para veicular que o mundo real será um mundo $\mathrm{p}$ ('Chove') e, usando a análise de Portner (2009) adiciona p ao CPS como candidata a ser incluída no CG e ser compartilhada como verdadeira entre os participantes da conversa. Daí ele veicula que o evento descrito por $\mathrm{p}$ é ou será fato.

Diferentemente de 'pode', 'podia' não causa restrição nos mundos da base modal àqueles que são mais próximos do real, também não os organiza segundo o curso normal dos eventos no mundo real: a fonte de ordenação é vazia. Isso porque o falante não tem evidências que sustentem a fatualidade de $\mathrm{p}$, por isso ele também não pode definir qual é o curso normal dos eventos. Por exemplo, para o falante proferir 'Podia chover', ele carece de evidências que indiquem a factualidade de p ('Chove'), e por isso veicula sua pouca confiança de que vá chover no mundo real. Assim, o falante expressa que, dada sua falta de evidências, conforme o andamento dos eventos no mundo real, não vai chover, e por isso ele acrescenta $\neg$ p ao CPS como candidata a ser incluída no CG. Com isso, o falante implica a não-factualidade de $\mathrm{p}$.

A pergunta que emerge é por que o falante expressa uma possibilidade sobre a qual ele não tem evidência, quebrando assim uma máxima griceana. A resposta é que o falante tem a intenção de veicular outros significados, como, por exemplo, seu desejo de que a proposição prejacente seja o caso, o que pode ser derivado da seguinte forma: o falante, sem evidência que indique a factualidade de $\mathrm{p}$, não restringe os mundos da base modal aos mundos mais semelhantes ao mundo real, implicando que o mundo real tanto pode ser um mundo p quanto um mundo $\neg p$, e incluindo $\neg$ p no CPS. Entretanto, ele ainda considera que $p$ é uma possibilidade, pois entre a amplitude de mundos não restritos por 'podia', há ao menos um em que $\mathrm{p}$ é o caso. $\mathrm{O}$ falante considera essa possibilidade, apesar de não ter evidências a favor dela, para expressar que gostaria que $\mathrm{p}$ fosse o caso. Nesse caso, ele veicula uma 
possibilidade trivial. Afinal, sem restrições há é certo pelo menos um mundo $\mathrm{p}$.

Ao longo da pesquisa que resultou nesta dissertação foram levantados muitos problemas e novas ideias foram surgindo para a explicação deles. Analisar o PB baseado em uma literatura densa, com uma linha de raciocínio teórico pouco difundida no Brasil, constituiu a principal dificuldade. As propostas aqui apresentadas devem ser vistas como um caminho a ser ainda percorrido para aos poucos chegarmos a uma descrição mais acurada da expressão da possibilidade no PB, visto que muitas respostas ainda precisam ser desenvolvidas e muitas questões foram provocadas pela própria pesquisa.

Apesar da necessidade de aprofundamento em vários tópicos, algumas intuições são importantes pontos de partida. Uma delas é a noção de distanciamento e da falta ou não de evidências. $O$ falante, com 'podia', se distancia da factualidade de $\mathrm{p}$, pois não quer se comprometer em incluir o mundo real entre os mundos em que p é verdadeira. Esse "distanciamento" ocorre ou por falta de evidência, como no caso da veiculação de não-factualidade, ou para veicular sugestão ou polidez, um tema não explorado nessa dissertação, mas que merece a atenção de um próximo trabalho. Esboçamos aqui um caminho para seguir na descrição da sugestão de da polidez veiculados por 'podia'. Com 'pode' o falante se respalda em evidências no mundo expressando uma possibilidade objetiva, e assim restringe os mundos de avaliação aos mundos mais próximos do real. A partir dessa restrição, inclui p no CPS e veicula maior comprometimento com a factualidade de $\mathrm{p}$, tornando-se mais convincente para o interlocutor concordar com o falante (dado que o falante se baseia em evidências), dando menos "espaço" para o interlocutor na decisão de adicionar p ao CG.

Esse parece ser um raciocínio correto para iniciarmos a investigação sobre a sugestão e a polidez veiculados por 'podia'. Com 'podia', o falante veicula que não "aposta" em p, ou seja, que não tem evidências que indiquem a factualidade de $\mathrm{p}$, que o respaldem para veicular que o mundo tende a ser um mundo $\mathrm{p}$. $\mathrm{O}$ falante apenas expressa que há uma possibilidade, e concede ao interlocutor maior participação em incluir ou não a prejacente no CG para compartilhá-la como verdadeira, provocando então uma leitura de polidez, de inclusão do ouvinte na definição do mundo real. 
Para seguirmos nessa proposta, precisamos reconhecer a insuficiência dos trabalhos em que nos baseamos. Por exemplo, a proposta de Portner (2009), que usamos para explicar a subjetividade expressa por 'pode' e 'podia', não explica porquê o falante tende a acreditar em p quando usa 'pode' e em $\neg$ p quando usa 'podia', pois na sua formulação não prevê a atuação do morfema de imperfeito, nem a adição de $\neg$ p ao CPS, como sugerimos logo acima. Fora isso, falta compreender melhor como ocorre essa restrição de mundos realizada por 'pode' e não por 'podia' e assim formalizar essa restrição. Outra questão que precisamos observar é se a polidez pode ser cancelada como o desejo e, assim, poder ser tratada como implicatura. Esta dissertação não tratou desse cancelamento. Além disso, outro passo para a compreensão da semântica de sentenças com 'pode' e 'podia' é investigar a interação desses modais com outros operadores, como a negação e a interrogação. Finalmente, é necessário compreender melhor a semântica de 'pode' e 'podia', e suas interfaces com a sintaxe (ver Hacquard, 2006) e com a prosódia, em especial a análise do morfema de imperfeito, para então sermos capazes de derivar com mais clareza os significados não-proposicionais veiculados por eles. 


\section{REFERÊNCIAS BIBLIOGRÁFICAS}

CONDORAVDI, C. 2002. Temporal Interpretation of Modals: modals for the present and for the past. Disponível em <http://wwwcsli.stanford.edu/ cleoc/AC/temp-mod.pdf $>$, acessado em 7 de Nov. de 2010 .

CORÔA, M. L. M. S. O Tempo nos verbos do português. São Paulo. Parábola Editorial, 2005.

COSTA, A.L.P. A variação entre formas de futuro do pretérito e pretérito imperfeito no português do Rio de Janeiro. Universidade Federal do Rio de Janeiro, 1997. Dissertação, Programa de Pósgraduação em Linguística da Universidade Federal do Rio de Janeiro. Rio de Janeiro, 1997.

FERREIRA, M. Event quantification and plurality. Tese de doutorado. Massachusetts Institute of Technology, Cambridge, 2005.

von FINTEL, K. Modality and Language. 2006. Disponível em <http://mit.edu/fintel/www/modality.pdf>, acessado em 06 nov. 2010.

von FINTEL, Kai; GILLIES, Anthony. An Opinionated Guide to Epistemic Modality. 2007. Disponível em < http://mit.edu/fintel/fintelgillies-2007-ose2.pdf>. Acessado em 05 novembro 2010.

von FINTEL, K.; IATRIDOU, S. How to say ought in foreign: the composition of weak necessity modals. In: Guéron, J.; LECARME, J.(eds). Time and Modality. Studies in Natural Language and Linguistic Theory. V. 75. Nova Iorque: Springer, 2008. Pp. 115 - 141.

GRICE, Paul. Logic and Conversation. In: COLE, P e MORGAN, J (Eds). Syntax and Semantics 3: Speech acts. Nova Iorque: Academic Pr, 1975. pp. 41-58.

HACQUARD, Valentine. Aspects of Modality. Massachussetts Institute of Technology, 2006. $214 \mathrm{f}$. Tese de doutorado. Massachussetts Institute of Technology , Departamento de Linguística e FiloMafalda. Orientador: Kai von Fintel. Cambridge, MA, 2006. Disponível em <http://www.ling.umd.edu/ hacquard/papers/hacquard_thesis.pdf >, acessado em 7 novembro 2010. 
HOCKETT, C. The origins of speech. In: Scientific American, 203: 8997, 1960.

IATRIDOU, Sabine. The grammatical ingredients of counterfactuality. In: Linguistics Inquiry. Vol. 31. Número 2. Cambridge: MIT Press, 2000. 231-270. pp. Disponível em <http://web.mit.edu/linguistics/people/faculty/iatridou/counterfactuality. pdf>. Acessado em: 7 nov. 2010.

ILARI, R. A expressão do tempo em português. São Paulo. Contexto, 1997.

IPPOLITO, Michela. Imperfect Modality. In: Guéron, J. \& Lecarme, J. (Ed.) The Syntax of Time: Current Studies in Linguistics, vol. 37. Cambridge: MIT Press, 2004.

KARAM, Lenara Meidel. A variação entre o Futuro do Pretérito, o Imperfeito e a perífrase com IR na fala do Rio Grande do Sul. Universidade Federal do Rio Grande do Sul, 2000. Dissertação (Mestrado em Letras) - Universidade Federal do Rio Grande do Sul, Coordenação de Aperfeiçoamento de Pessoal de Nível Superior. Orientadora: Ana Maria Stahl Zilles. Porto Alegre, 2000.

KRATZER, Angelika. The notional category of modality. In: Eikmeyer, H-J.; Rieser, H. (Ed.). Word, worlds, and contexts: new approaches to word semantics. Berlin: W. de Gruyter, 1981. p. 38-74.

Modality. In: von Stechow, A.; Wunderlich, D. (eds). Semantics: an international handbook of contemporary research. Berlin; New York: W. de Gruyter, 1991. p. 639-50.

- Modals and conditionals again. 2008. A ser publicado pela Oxford University. Disponível em <http://semanticsarchive.net/Archive/Tc2NjA1M/must_can_new.pdf>. Acessado em : 7 novembro 2010.

The notional category of modality. 2010. A ser publicado pela Oxford University. Disponível em <http://semanticsarchive.net/Archive/Tc2NjA1M/must_can_new.pdf>. Acesso em : 7 novembro 2010. 
LOBATO, L.M.P. Os verbos auxiliares em português contemporâneo. Critério de auxiliaridade. In: L.M.P. LOBATO et al. Análises linguísticas. Petrópolis, Vozes, 1975.

LUNGUINHO, M. V. S. Sobre a concordância modal em Português. In: Cadernos de Linguagem e Sociedade / Papers on language and society / Denize Elena Garcia da Silva (Ed.). v.11. no. 2 Brasília : Thesaurus, 2010.

, M. A Ordem dos Verbos Auxiliares: uma análise em termos de traços. Dissertação de Mestrado. Brasília: Universidade de Brasília, 2005.

LYONS, J. Semantics 2. Cambridge: Cambridge University Press, 1977.

NEVES, Maria Helena Moura. A modalidade. In: KOCH, I.G.V. (org.) Gramática do português falado VI. Desenvolvimentos. Campinas: Ed. da UNICAMP/FAPESP, 1996.

MIOTO, Carlos; SILVA, Maria C. F.; LOPES, Ruth E. V. Novo manual de sintaxe. 3. ed. Florianópolis: Insular, 2007. 280 p.

MORTARI, C. Introdução à Lógica. São Paulo: Editora Unesp, Imprensa Oficial do Estado, 2001.

MORTARI, C; PIRES DE OLIVEIRA, R. Modais e condicionais nas línguas naturais: uma introdução à semântica de mundos possíveis. Material em Preparação. 2010.

NINAN, D. Two puzzles about deontic necessity. In: Gajewsky, J., Hacquard, V., Nickel, B., e Yalcin, S. (eds). New work on modality. Vol 51. MIT Working Papers in Linguistics. Cambridge, 2005. PP. 149-178.

NUYTS, J. Subjetivity as na evidential dimension in epistemic modal expressions. In: Journal of Pragmatics, 33. 2001. Pp. 383 - 400.

OLIVEIRA, M. F. F. P. Para uma semântica e pragmática de dever e poder. 1988. 439 f. Tese (Doutorado em Linguística Portuguesa) Faculdade de Letras. Universidade do Porto, Porto, 1988. 
PESSOTTO, A. L.; PIRES DE OLIVEIRA, R. O que há de diferente entre 'pode' e 'podia'?. In: 8 Encontro do Círculo de Estudos Linguísticos do Sul - CELSUL, 2008, Porto Alegre. Anais do $8^{\circ}$ Encontro do Celsul. Pelotas : Editora da Universidade Católica de Pelotas, 2008.

PINKER, S. Do que é feito o pensamento: a língua como janela para a natureza humana. Tradução: Fernanda Ravagnani. São Paulo: Companhia das Letras, 2008.

PIRES DE OLIVEIRA, Roberta; PESSOTTO dos SANTOS, Ana Lúcia. Wishing it were: podia and the implicature of desire in Brazilian Portuguese. In: LIMA, S. (ed) Proceedings of SULA5 - SEMANTIC FOR UNDER-REPRESENTED LANGUAGES IN AMERICAS. University of Massachusetts Occasional Papers. V. 41. Amherst: GLSA (Graduate Linguistics Students' Association), 2011.

PIRES DE OLIVEIR, R.; PESSOTTO, A.L. Imperfective modals in Brazilian Portuguese. In: VIII WORKSHOP ON FORMAL LINGUISTICS. São Paulo: Universidade de São Paulo, 2010.

PIRES DE OLIVEIRA, R.; Scarduelli, J. . Explicando as diferenças semânticas entre 'ter que' e 'deve': uma proposta em semântica de mundos possíveis. Alfa Revista de linguística (UNESP. São José do Rio Preto. Online), v. 52, p. 215-236, 2008.

PONTES, Eunice. Verbos Auxiliares em Português. Petrópolis: Vozes, 1973.

PORTNER, Paul. Modality. Nova Iorque: Oxford University Press, 2009.

Da SILVA, Teresa S. A Alternância entre o Pretérito imperfeito e o futuro do pretérito na fala de Florianópolis. Universidade Federal de Santa Catarina, 1998. 134 p. Dissertação de Mestrado. Programa de pósgraduação em Linguística, Universidade Federal de Santa Catarina. Florianópolis, 1998.

STALNAKER, Robert. Indicative conditionals. In: Philosophia 5. 1975. pp. 269-286. 
STOWELL, Tim. Tense and modals. In Jacqueline Guéron \& Jacqueline Lecarme (eds.), The syntax of time, p. 621-636. Cambridge: MIT Press, 2004.

TANCREDI, C. A multi model theory of I-semantics, parte 1. In: Modals. Keio University, 2007. Disponível em <http://semanticsarchive.net/Archive/WFkYjU1Y/>. Acesso: 7 novembro 2010. 